\title{
Gene expression profiling of the
} venom gland from the Venezuelan mapanare (Bothrops colombiensis) using expressed sequence tags (ESTs)

\author{
Montamas Suntravat ${ }^{1}$, Néstor L. Uzcategui ${ }^{2}$, Chairat Atphaisit ${ }^{1}$, Thomas J. Helmke ${ }^{1}$ Sara E. Lucena', \\ Elda E. Sánchez ${ }^{1 *}$ and A. Rodríguez Acosta ${ }^{2}$
}

\begin{abstract}
Background: Bothrops colombiensis is a highly dangerous pit viper and responsible for over $70 \%$ of snakebites in Venezuela. Although the composition in B. colombiensis venom has been identified using a proteome analysis, the venom gland transcriptome is currently lacking.

Results: We constructed a cDNA library from the venom gland of B. colombiensis, and a set of 729 high quality expressed sequence tags (ESTs) was identified. A total number of 344 ESTs (47.2\% of total ESTs) was related to toxins. The most abundant toxin transcripts were metalloproteinases (37.5\%), phospholipases $A_{2} S\left(P L A_{2}, 29.7 \%\right)$, and serine proteinases (11.9\%). Minor toxin transcripts were linked to waprins (5.5\%), C-type lectins (4.1\%), ATPases (2.9\%), cysteine-rich secretory proteins (CRISP, $2.3 \%$ ), snake venom vascular endothelium growth factors (SVVEGF, $2.3 \%$ ), L-amino acid oxidases (2\%), and other putative toxins (1.7\%). While 160 ESTs (22\% of total ESTs) coded for translation proteins, regulatory proteins, ribosomal proteins, elongation factors, release factors, metabolic proteins, and immune response proteins. Other proteins detected in the transcriptome (87 ESTs, $11.9 \%$ of total ESTs) were undescribed proteins with unknown functions. The remaining 138 (18.9\%) cDNAs had no match with known GenBank accessions.
\end{abstract}

Conclusion: This study represents the analysis of transcript expressions and provides a physical resource of unique genes for further study of gene function and the development of novel molecules for medical applications.

Keywords: cDNA library, Bothrops colombiensis, Viperidae, Expressed sequence tags

\section{Background}

Snake venoms, mainly from Viperidae families are rich reservoirs of metalloproteinases, serine proteinases, and phospholipase $\mathrm{A}_{2}\left(\mathrm{PLA}_{2}\right)$ [1-6], inducing a diversity of hemostatic effects such as blood coagulation, hemorrhage, and platelet aggregation. Hemorrhage is mainly caused by snake venom zinc-dependent metalloproteinases, which digest components of the extracellular matrix (ECM) proteins resulting in bleedings [4].

\footnotetext{
*Correspondence: elda.sanchez@tamuk.edu

${ }^{1}$ National Natural Toxins Research Center, Department of Chemistry,

Texas A and M University-Kingsville, Kingsville, USA

Full list of author information is available at the end of the article
}

Bothrops snakes belonging to the family Viperidae are the major cause of snakebite morbidity and mortality in Central and South America [7]. Bothrops colombiensis bites were responsible for over $70 \%$ of accidents in Venezuela annually $[8,9]$. Symptoms of Bothropoid envenoming include edema, pain, myonecrosis, hemorrhage, and systemic effects such as hemostatic disorders and cardiovascular shock [10]. Using a proteome analysis, many biological proteins, mainly metalloproteinases and PLA $\mathrm{A}_{2}$, were identified in B. colombiensis venom [11]. However, some proteins in small quantity may be difficult to identify using a proteomic approach.

Transcriptome analysis based on the analysis of expressed sequence tag (ESTs) provides insight into the 
regulation of snake venom production and catalogues of transcripts including putative new toxins, toxin isoforms, or low abundant toxins that may be difficult to identify by the proteomic approach [12-19]. Also, with advances in bioinformatics and recombinant DNA technology, venom gland transcriptomic data is an excellent tool for understanding the molecular evolution, developing potential resources for antivenom design and novel therapeutic agents, and studying structure-function relationships.

To provide additional insight into the molecular diversity of venom composition, and identify novel and low abundant toxins, we constructed a cDNA library from the venom glands of a single $B$. colombiensis snake. This database provides a primary assembly of transcripts defined from this species and individual specimen, in which several new venom molecules have been recognized, and could be used as a foundation for venomic studies and evolutionary investigation.

\section{Results and discussion}

\section{Sequencing and assembly results}

The production of this primary cDNA library is an important phase in the upcoming varying field of Bothrops gland genomic investigation, gene expression, molecular markers, gene sequencing for structural analyses and possibly for gene screening. Here we constructed a cDNA library from the venom glands of a single snake to preclude ambiguity by intraspecies variation in venom components, which will provide interest in the comparison of the genes expressed among closely related species and within the same species for future work. Therefore, these ESTs may not be representative of all $B$. colombiensis. The cDNA library was generated with a titer of $1.75 \times 10^{8}$ colonyforming units $(\mathrm{cfu}) / \mathrm{mL}$. The 2016 clones from the cDNA library were randomly selected and sequenced from the $5^{\prime}$ end. A total of 729 sequences with an average insert size of $593 \mathrm{bp}$ (ranging from 129 to $1265 \mathrm{bp}$ ) were obtained after removing low-quality sequences of less than $100 \mathrm{bp}$ and contaminating vector sequences. Sequence analysis revealed that 729 high-quality sequences of which 230 (31.6\%) sequences were singletons and the other $499(68.4 \%)$ were clustered into 57 contigs assembly by two or more ESTs (Additional file 1). Most of these transcripts matched with snake toxins (344 ESTs in 31 clusters, $47.2 \%)$ as shown in Fig. 1 and Table 1. The other $22 \%$ (160 ESTs in 119 clusters) are classified as non-toxins, which are likely related to cellular process proteins such as ribosomal proteins, translation proteins, regulatory proteins, and elongation factors, and $11.9 \%$ of ESTs (87 ESTs in 64 clusters) are hypothetical proteins with no functional attributes (unknown). The remaining $18.9 \%$ (138 ESTs in 73 clusters) had no hits with any sequences available in the GenBank database. A total number of

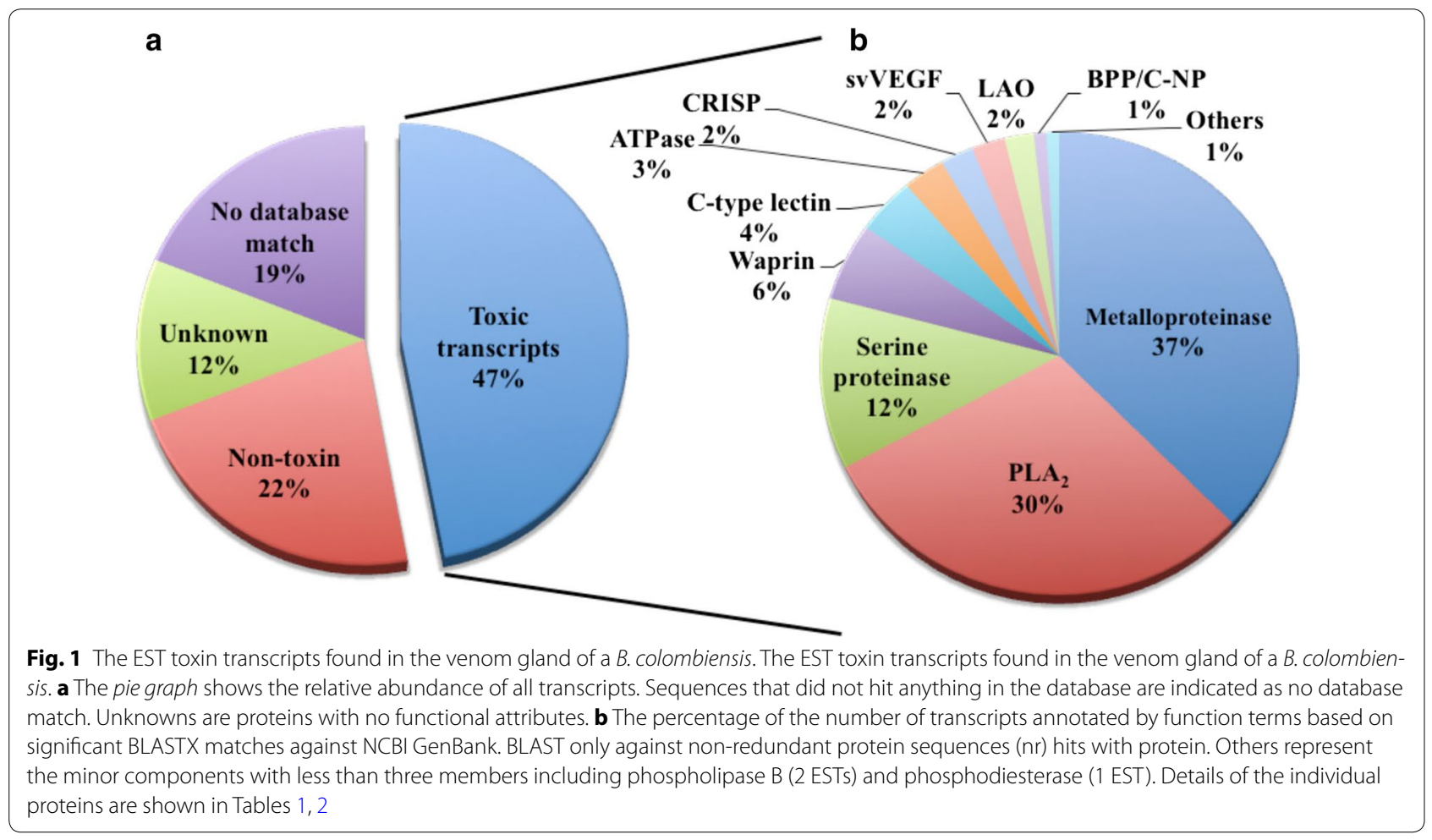


Table 1 Relative abundances of putative toxins identified in B. colombiensis venom gland transcriptome

\begin{tabular}{|c|c|c|c|c|c|}
\hline Toxins & No. of ESTs & No. of clusters & $\begin{array}{l}\text { Redundancy (clones/ } \\
\text { clusters) }\end{array}$ & $\%$ Of total & $\begin{array}{l}\% \text { Of total toxin } \\
\text { transcripts }\end{array}$ \\
\hline Metalloproteinase & 129 & 10 & 12.9 & 17.7 & 37.5 \\
\hline $\mathrm{PLA}_{2}$ & 102 & 3 & 34.0 & 14.0 & 29.7 \\
\hline Serine proteinase & 41 & 2 & 20.5 & 5.6 & 11.9 \\
\hline Waprin & 19 & 1 & 19.0 & 2.6 & 5.5 \\
\hline C-type lectin & 14 & 4 & 3.5 & 1.9 & 4.1 \\
\hline ATPase & 10 & 2 & 5.0 & 1.4 & 2.9 \\
\hline CRISP & 8 & 2 & 4.0 & 1.1 & 2.3 \\
\hline sVVEGF & 8 & 1 & 8.0 & 1.1 & 2.3 \\
\hline LAO & 7 & 2 & 3.5 & 1.0 & 2.0 \\
\hline $\mathrm{BPP} / \mathrm{C}-\mathrm{NP}$ & 3 & 1 & 3.0 & 0.4 & 0.9 \\
\hline Phospholipase B & 2 & 2 & 1.0 & 0.3 & 0.6 \\
\hline Phosphodiesterase & 1 & 1 & 1.0 & 0.1 & 0.3 \\
\hline Total & 344 & 31 & - & 47.2 & 100.0 \\
\hline
\end{tabular}

$B P P / C-N P$ Bradykinin-potentiating and C-type natriuretic peptide, CRISP cysteine-rich secretory protein, $L A O$ L-amino acid oxidase, $P L A_{2}$ phospholipase $\mathrm{A}_{2}$, sVVEGF snake venom vascular endothelium growth factor

108 representative ESTs from an individual cDNA clone were deposited in the NCBI EST database (http://www. ncbi.nlm.gov/dbEST) under accession numbers [dbEST: JZ880059-JZ880166] (Additional file 2).

The 344 putative toxin-coding ESTs were further clustered and classified into 12 different toxin families using BLAST for functional annotation. These EST clusters coding for the main toxins are listed in Table 2. The most frequent transcripts coding for toxins were from metalloproteinases, followed by phospholipase $\mathrm{A}_{2} \mathrm{~S}\left(\mathrm{PLA}_{2} \mathrm{~s}\right)$ and serine proteinases, which accounted for $79.1 \%$ of the total toxin ESTs. The preponderance of these proteins was expected, as this snake belongs to the genus Bothrops, which contain venom most notable for local tissue damage such as edema, hemorrhage, and necrosis [8, 20-23]. Notably, experimental examples of these activities of the $B$. colombiensis venom supporting our findings have been published in the literature $[1-3,8]$. However, the toxin transcript expression levels among Bothrops species were varied in their relative proportions (Fig. 2 and Additional file 3), which may explain relevant differences observed in the venom action of the species of Bothrops.

\section{Major toxins \\ Metalloproteinases}

The highest number of toxin ESTs in B. colombiensis were metalloproteinases (37.5 \%). This abundance of metalloproteinases has been already observed for other Bothrops transcriptomes. The percentages for these reported metalloporteinases range, approximately, between 25-80\% and the highest reported was for B. alternatus (urutu) representing $81.4 \%$ of the toxins transcripts [24]. Other Bothrops with a high expression of metalloproteinase genes were $B$. atrox (61.6\%) [25] and B. jararaca (29.9$53.1 \%$ ) [26, 27] (Fig. 2; Additional file 3).

Metalloproteinases are crucial components in hemostasis as well as in thrombosis [28]. Snake venom metalloproteinases (SVMPs) are responsible for the hemorrhagic condition, which is one of the most severe consequences of Viperidae snake envenomations. SVMPs are classified into three subclasses established on their domain structure $[29,30]$. These SVMP groups are: The P-I class (20$30 \mathrm{kDa}$ ) comprises a single metalloproteinase domain. The P-II class (30-60 kDa) involves a metalloproteinase domain and a disintegrin domain. The P-III class (60$100 \mathrm{kDa}$ ) comprises a metalloproteinase, disintegrin-like and cysteine-rich domains [31]. The former P-IV class, a P-III structure which includes an additional C-type lectin-like domain was re-classified into a P-IIId subclass.

When a blood vessel is damaged by SVMPs, these circulating enzymes adhere and accumulate on the disrupted surface of the subendothelium and activate platelets. The aggregation and adhesion of these cells to the subendothelium are facilitated through the interaction of extracellular matrix proteins with their agonist receptors, namely integrins, on the platelet membrane [32, 33]. This intraluminal cell adhesion may initiate the atherothrombotic process leading to intravascular thrombosis [34-36]. On the other hand, snake venom hemorrhagic metalloproteinases can also digest several blood coagulation components, counting fibrinogen and von Willebrand factor, which amplify the hemorrhagic activity $[20,37]$. As described above, the disintegrin domain is part of snake venom metalloproteinases, and mostly 
Table 2 Relative abundances of putative toxin-encoding clusters identified in B. colombiensis venom gland transcriptome

\begin{tabular}{|c|c|c|c|c|}
\hline Clusters & No. ESTs & HIT ID & Annotation & Evalue \\
\hline \multicolumn{5}{|c|}{ Metalloproteinases } \\
\hline $\mathrm{BCO1}$ & 107 & P83512.2 & Snake venom metalloproteinase BaP1 [Bothrops asper] & $0.00 \mathrm{E}+00$ \\
\hline $\mathrm{BCO2}$ & 1 & ABP48735.1 & Nonhemorrhagic metalloprotease MP-II, partial [Bothrops jararacussu] & $9.80 \mathrm{E}-27$ \\
\hline $\mathrm{BCO3}$ & 2 & ADO21506.1 & MP_Ilb1 SVMP precursor, partial [Bothrops neuwiedi] & $0.00 \mathrm{E}+00$ \\
\hline $\mathrm{BCO} 4$ & 1 & Q7SZD9.1 & Zinc metalloproteinase/disintegrin ussurin [Gloydius ussuriensis] & $4.40 \mathrm{E}-21$ \\
\hline BC05 & 5 & Q98UF9.3 & Zinc metalloproteinase-disintegrin-like HF3 [Bothrops jararaca] & $0.00 \mathrm{E}+00$ \\
\hline $\mathrm{BCO6}$ & 7 & Q2LD49.1 & Zinc metalloproteinase-disintegrin-like TSV-DM [Trimeresurus stejnegeri] & 1.30E-75 \\
\hline $\mathrm{BCO7}$ & 3 & $\mathrm{C} 5 \mathrm{H} 5 \mathrm{D} 4.1$ & Zinc metalloproteinase-disintegrin-like batroxstatin-3 [Bothrops atrox] & $4.00 \mathrm{E}-56$ \\
\hline $\mathrm{BC08}$ & 1 & Q98UF9.3 & Zinc metalloproteinase-disintegrin-like HF3 [Bothrops jararaca] & $0.00 \mathrm{E}+00$ \\
\hline BC09 & 1 & Q8UVG0.1 & Zinc metalloproteinase-disintegrin-like berythractivase [Bothrops erythromelas] & $0.00 \mathrm{E}+00$ \\
\hline $\mathrm{BC} 10$ & 1 & C9E1S0.1 & Zinc metalloproteinase-disintegrin-like VMP-III [Agkistrodon piscivorus leucostoma] & $1.00 \mathrm{E}-14$ \\
\hline Total ESTs & 129 & & & \\
\hline \multicolumn{5}{|l|}{$\mathrm{PLA}_{2} \mathrm{~S}$} \\
\hline BC11 & 71 & P24605.3 & Basic phospholipase $\mathrm{A}_{2}$ homolog 2, myotoxin II [Bothrops asper] & $3.00 E-88$ \\
\hline $\mathrm{BC} 12$ & 1 & P20474.2 & Basic phospholipase $A_{2}$ myotoxin III [Bothrops asper] & $5.30 E-13$ \\
\hline $\mathrm{BC} 13$ & 30 & $5.40 \mathrm{E}-82$ & Acidic phospholipase $\mathrm{A}_{2}$ BmooPLA $_{2}$ [Bothrops moojeni] & $5.40 \mathrm{E}-82$ \\
\hline Total ESTs & 102 & & & \\
\hline \multicolumn{5}{|c|}{ Serine proteinases } \\
\hline BC14 & 39 & P04971.1 & Thrombin-like enzyme batroxobin [Bothrops atrox] & $3.50 E-146$ \\
\hline $\mathrm{BC} 15$ & 2 & Q5W959.1 & Snake venom serine protease HS114 [Bothrops jararaca] & $5.90 \mathrm{E}-109$ \\
\hline Total ESTs & 41 & & & \\
\hline \multicolumn{5}{|l|}{ Waprin } \\
\hline $\mathrm{BC} 16$ & 19 & BAN89446.1 & Waprin, partial [Ovophis okinavensis] & $1.0 \mathrm{E}-17$ \\
\hline Total ESTs & 19 & & & \\
\hline \multicolumn{5}{|c|}{ C-type lectins } \\
\hline BC18 & 8 & P0C930.1 & Snaclec bothroinsularin subunit beta [Bothrops insularis] & $2.20 E-49$ \\
\hline $\mathrm{BC} 19$ & 3 & BAN89423.1 & C-type_lectin_beta-subunit [Ovophis okinavensis] & $1.00 E-12$ \\
\hline $\mathrm{BC} 20$ & 2 & BAP39929.1 & C-type lectin B subunit, partial [Protobothrops elegans] & $3.60 E-38$ \\
\hline $\mathrm{BC} 21$ & 1 & BAP39964.1 & C-type lectin F IX/X B [Protobothrops flavoviridis] & $5.5 \mathrm{E}-79$ \\
\hline Total ESTs & 14 & & & \\
\hline \multicolumn{5}{|l|}{ ATPase } \\
\hline BC22 & 9 & ACJ46370.1 & ATPase 6 [Agkistrodon piscivorus] & $2.70 E-93$ \\
\hline BC23 & 1 & ETE73855.1 & V-type proton ATPase subunit e 1 [Ophiophagus hannah] & $9.70 E-47$ \\
\hline Total ESTs & 10 & & & \\
\hline \multicolumn{5}{|l|}{ CRISP } \\
\hline BC24 & 7 & BAP39957.1 & Cysteine-rich venom protein, partial [Protobothrops flavoviridis] & 1.10E-158 \\
\hline BC25 & 1 & ETE59024.1 & Cysteine-rich protein 1 [Ophiophagus hannah] & $6.60 \mathrm{E}-49$ \\
\hline Total ESTs & 8 & & & \\
\hline \multicolumn{5}{|l|}{ sVVEGF } \\
\hline BC26 & 8 & Q90X24.1 & Snake venom vascular endothelial growth factor toxin [Bothrops insularis] & $3.60 E-93$ \\
\hline Total ESTs & 8 & & & \\
\hline \multicolumn{5}{|l|}{ LAO } \\
\hline $\mathrm{BC} 27$ & 6 & B5AR80.1 & L-amino-acid oxidase [Bothrops pauloensis] & $0.00 \mathrm{E}+00$ \\
\hline BC28 & 1 & X2JCV5.1 & L-amino-acid oxidase [Cerastes cerastes] & $5.30 \mathrm{E}-39$ \\
\hline Total ESTs & 7 & & & \\
\hline \multicolumn{5}{|l|}{$\mathrm{BPP} / \mathrm{C}-\mathrm{NP}$} \\
\hline BC29 & 3 & BAP39952.1 & Bradykinin-potentiating and C-type natriuretic peptides, partial [Protobothrops flavoviridis] & $2.00 \mathrm{E}-09$ \\
\hline Total ESTs & 3 & & & \\
\hline
\end{tabular}


Table 2 continued

\begin{tabular}{|c|c|c|c|c|}
\hline Clusters & No. ESTs & HIT ID & Annotation & E value \\
\hline \multicolumn{5}{|c|}{ Phospholipase B } \\
\hline $\mathrm{BC} 30$ & 1 & BAN82026.1 & Phospholipase B [Protobothrops flavoviridis] & $3.70 \mathrm{E}-152$ \\
\hline $\mathrm{BC} 31$ & 1 & F8S101.1 & Phospholipase B [Crotalus adamanteus] & $3.60 \mathrm{E}-107$ \\
\hline Total ESTs & 2 & & & \\
\hline \multicolumn{5}{|c|}{ Phosphodiesterase } \\
\hline $\mathrm{BC} 32$ & 1 & BAN89425.1 & Phosphodiesterase [Ovophis okinavensis] & $0.00 \mathrm{E}+00$ \\
\hline Total EST & 1 & & & \\
\hline
\end{tabular}

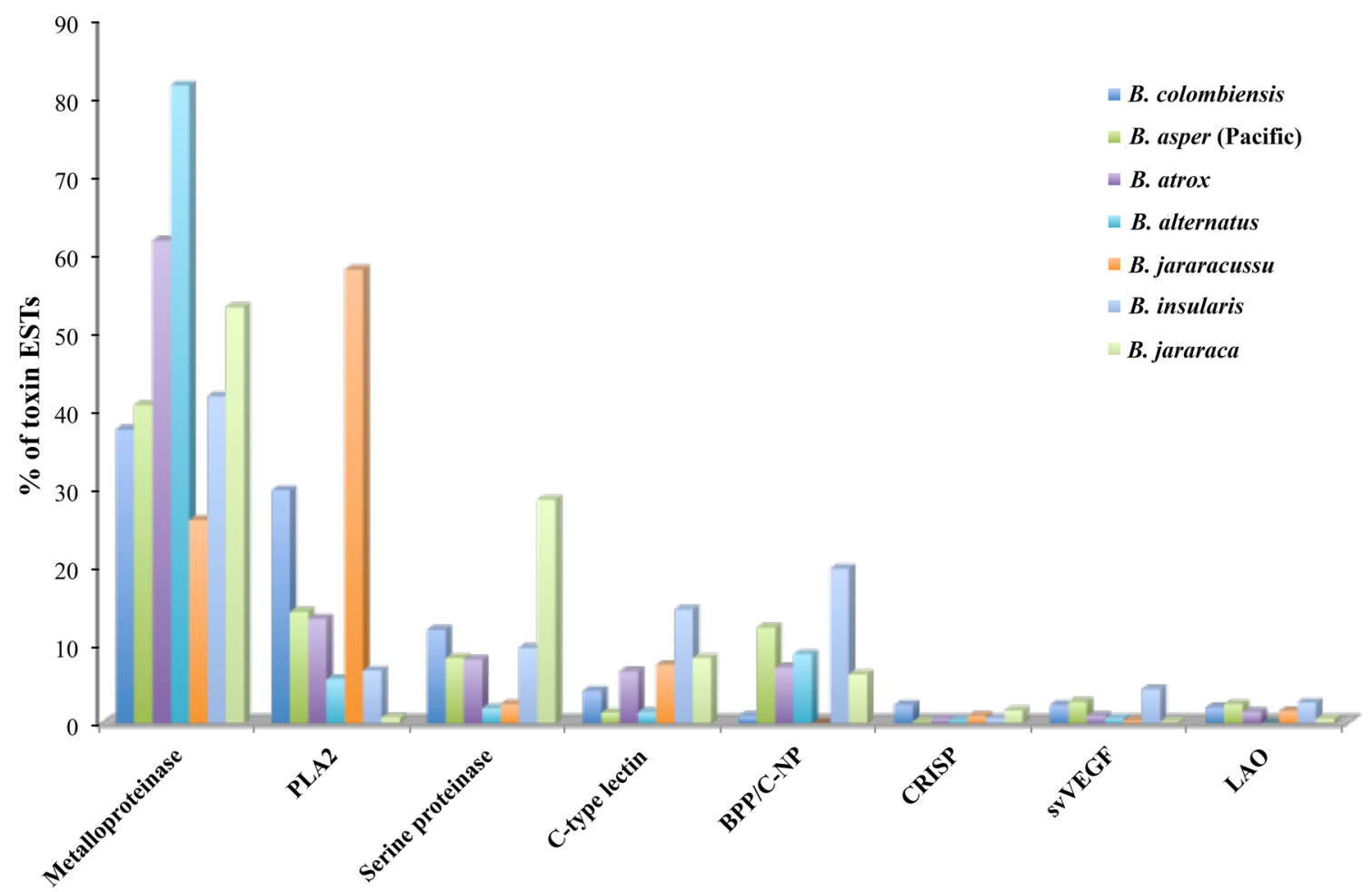

Fig. 2 The putative cellular protein transcripts (non-toxins) from B. colombiensis according to their cellular functions

derived by proteolytic processing of the protein precursor to produce a free disintegrin [38-40]. Disintegrins are low molecular weight proteins ranging from 49-84 amino acids in length that are known to be involved in cell adhesion ligand recognition, binding specifically to integrin receptors on the cell surface and also exhibiting anti-platelet aggregation activity. Because of their low molecular weight and ability to block integrin activity, both native and recombinant disintegrins have been widely investigated for their anti-cancer activities in biological systems in vitro and in vivo [41-48].

In the current work, we identified 129 putative metalloproteinases, which were grouped into five contigs and five singletons (Fig. 1, Tables 1, 2). These 10 unique SVMP clusters corresponding to partial cDNA sequences were named BC01-BC10. The B. colombiensis transcriptome contained transcripts for P-I $(83.3 \%$ of the total SVMP ESTs and $31.4 \%$ of total toxin transcripts, clusters BC01 and BC02), P-II (2.3\% of the total SVMP ESTs and $0.9 \%$ of total toxin transcripts, $\mathrm{BCO} 3$ and $\mathrm{BC} 04$ ), and P-III (14 \% of the total SVMP ESTs and $5.2 \%$ of total toxin transcripts, $\mathrm{BC} 05-\mathrm{BC} 10)$. The $\mathrm{BC} 01$ cluster showed the most abundant metalloproteinase cluster $(83 \%$ of the total SVMP ESTs and $31.1 \%$ of total toxin transcripts). It posesses a 20-residue signal sequence, a conserved $\mathrm{M} 12 \mathrm{~B}$ propeptide region, and a reprolysin domain with a zinc-binding motif (HEXXHGXXH motif). NCBI BLAST analysis showed that the deduced amino acid sequence of the partial PI-SVMP cluster BC01 had $87.7 \%$ sequences identity with metalloproteinase BaP1 (P-I 


\begin{tabular}{|c|c|}
\hline & $\mathrm{ce} \longleftarrow \longrightarrow$ \\
\hline JZ880164 & RELPKGAVQPKYEDAMQYEFKVNGEPVVLHLEKNKELLFSEDYSETHYSPDGREITTYPPVE 100 \\
\hline & VTELPKGAVQPKYEDAMQYEFKVNGEPVVLHLEKNKELFSEDYSETHYSPDGRE ITTYPPVE \\
\hline JZ880067 & MIQLLLVTICLAVFPYQGSSI I LESGNVNDYEVVY PRKVTEL PKGAVQPKYEDAMQYEFKVNGEPVVLHLEKNKELFSEDYSETHYSPDGRE ITTYPPVE \\
\hline JZ880076 & MIQLLLVTICLAVFPYQGSSI IQESGNVNDYEVVYPRKVTELPKGAVQPKYEDAMOOYEFKVNGEPVVLHLEKNKELFSEDYSETHYSPDGREITTYPPVE \\
\hline BaP1 [P83512.2] & MIEVLIVTICLAVFPYQGSSIILESGNVNDYEVVYPRKVTELPKGAVQPKYEDAMQYEFKVNGEPVVLHLEKNKGLFSEDYSETHYSPDGRKIITYPSFE \\
\hline Atrolysin-C [Q90392.1] & I MIEVVLVTICLAVFPYQGSSIILESGNVNDYEVVYPRKVTALPKGAVQPKYEDAMQYELKVNGEPVVLHLEKNKELESKDYSETHYSPDGRKITTNPSVE \\
\hline AclVMP-I [Q92031.1] & MIQVLLVTLCLAAFPYQGSSIILESGNVNDYEVVYPRKVTPVPRGAVQPKYEDAMOYEFKVNGEPVVLHLEKNKGLFSEDYSETHYSPDGREITTYPLVE \\
\hline \multirow[t]{2}{*}{ AplVMP-I [B7U492.1] } & QVLLIVTICLAAFPYQGSSI I LESGNVNDYE IVYPRKVTPVPRGAVQPKYEDAMQYELKVNGGEPVVLHLEKNKGLESEDYSETHYSPDGREITTYPLVE \\
\hline & Pro-peptide region \\
\hline JZ880164 & DHCYYRGRIENDADSTASISACNGLKGHFKIOGETYLIEPLKLSDSEAHAVYKYENVEKEDEAPKMCGVTETNWESYEPIKKASOSNLTPEOOKFSPRHI 200 \\
\hline & DHCYYRGRIENDADSTAS ISACNGLKGHEKIQGETYLIE PLKLSDSEAHAVYKY ENVEKEDEAPKMCGVTETNWESYEPIKKASQSNLTPEQQKF SPRHI \\
\hline JZ880067 & DHCYYRGRI IENDADSTASISACNGLKGHFKIQGETYLIEPLKLSDSEAHAVYKYENVEKEDEAPKMCGVTETNWESYEPIKKASQSNLTPEQQKFSPRHI \\
\hline JZ880076 & DHCYYRGRIENDADSTASISACNGLKGHFKIQGETYLIEPLKLSDSEAHAVYKYENVEKEDEAPKMCGVTETNWESYEPIKKASQSNLTPEQQKFSPRHI \\
\hline BaP1 [P83512.2] & DHCYYHGRIENDADSTASISACNGLKGHFKLQGETYLIEPLKLSDSEAHAVYKYENVEKEDEAPKMCGVTETNWESYEPIKKASQSNLTPEQQRFSPRHI \\
\hline Atrolysin-C [Q90392.1] & DHCYYRGRIENDADSTASISACNGLKGHFKLQGELYIIE PLELSDSEAHAVFRI ENVEKEDEAPKMCGVTQN-WESYEPIKKASDLNLNPDQQNLPQRYI \\
\hline & DHCYYHGRIENDADSTAS ISACNGLKGHEKLQGEMYLIEPLELSDSEAHAVYKYENVEKEDEAPKMCGVT QN-WESYEPI \\
\hline \multirow[t]{2}{*}{ AplVMP-I [B7U492.1] } & DHCYYHGRI ENDADSTAS ISTCNGLKGHFKLQGEMYLIE PLE LS DSEAHAVYKYENVEKEDEAPKMCGVTQN-WESYEPTKKAFQLNLT PEQQGF PQRYV \\
\hline & Metalloproteinase domain \\
\hline JZ880164 & ELVVVADHGMFKKYNSNINTIRKWVHEMVNSMNGFYRPMDMHLSLANLEVWSKKDLIINVQKDSSETLKSFGEWRERDLLPHISHDNAQLLTTTVFDKNVI 300 \\
\hline JZ880075 & ELVVVADHGMFKKYNSNINTIRKWVHEMVNSMNGFYRPMDMHLSLANLEVWSKKDL INVQKDSSETLKSFGEWRERDLLPHISHDNAQLLTTTVF TKNVI \\
\hline & NSNLNTIRKWVHEMVNSMNGFYRPMDM \\
\hline JZ880076 & ELVVVADHGMFKKYNSNINTIRKWVHEMVNSMNGFYRPMDMHL \\
\hline $\mathrm{BaP1}[\mathrm{P} 83512.2]$ & ELAVVADHG IF TKYNSNINTIRTRVHEMLNTVNGF YRSVDVHAPLANLEVWSKQDLIKVQKDSSKTLKSFGEWRERDLI \\
\hline Atrolysin-C [090392.1] & 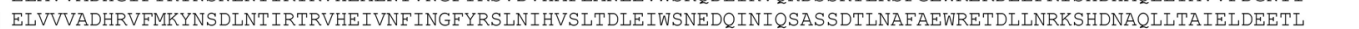 \\
\hline & 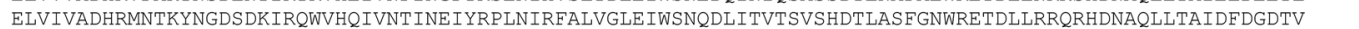 \\
\hline APIVMP-I [B7U492.1] & 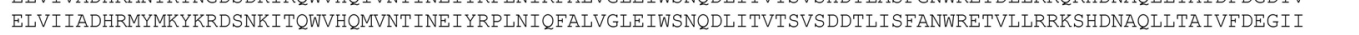 \\
\hline & GRAYLSKMCDPRQSVGVVMDHSKKNLQVAVTMAHELGHNLGMHHDGNQGHWDAAS-CIMAEPLS-EVLSYEFSDW-----------SPESISNVSY--- 400 \\
\hline & JMDHSKKNLQVAVTMA HELGHNLGN \\
\hline & ------------ \\
\hline & \\
\hline $\mathrm{BaP1}[\mathrm{P} 83512.2]$ & AYTGGMCDPRHSVGVVRDHSKNNLWV \\
\hline Atrolysin-C [Q90392.1] & GLAPLGTMCDPKLSIGIVQDHSPINLLMGVTMA HELGHNLGMEHD \\
\hline AClVMP-I [Q92031.1] & GLAYVGGMCQLKHSTGVIQDHSA INLLVIVLTMAHELGHNLGMNHDGNQCHCGANS-CVMPSVLS-DQPSKLFSDCSKKDYQTFLPVINNPQCI LNKPLRTD \\
\hline \multirow[t]{2}{*}{ AplVMP-I [B7U492.1] } & GRAPLAGMCDPNRSVGTVQDHSK INFRVAI IMAHE IGHNLGMGHDDNSCTCGGYS-CIMLPRLS-KQPSKLFSDCSKKDYLTFLKVKNPQCI LNKPLRTD \\
\hline & \\
\hline & $-10-417$ \\
\hline & 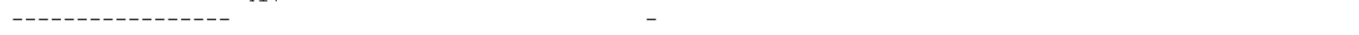 \\
\hline & ------------------ \\
\hline & ------ \\
\hline $1[\mathrm{P} 83512.2]$ & -----VSGNELLEAGE- \\
\hline in-C [Q90392.1] & I PVSTPVSGNELLEAGEE \\
\hline AclVMP-I [Q92031.1] & TASTPVSGNELLLEA--- \\
\hline ApIVMP-I [B7U492.1] & TVSTPVSGNELLEA--- \\
\hline \multicolumn{2}{|c|}{$\begin{array}{l}\text { Fig. } 3 \text { The partially deduced amino acid sequence of the representative clones [JZ880164, JZ880075, JZ880067, and JZ880076] from the most } \\
\text { abundant PI-SVMP cluster BC01. Predicted amino acid sequences of transcripts coding for the signal peptide, pro-peptide region, and partial a met- } \\
\text { alloproteinase catalytic domain with a zinc-binding motif. The signal peptide is highlighted in grey color, and the cysteine-switch motif (PKMCGVT) } \\
\text { is bolded. The zinc-binding site is underlined. Each domain is indicated by arrows. The major isoform of cluster BC01 is aligned with BaP1 [P83512.2] } \\
\text { from B. asper, atrolysin-C [Q90392.1] from C. atrox, AcIVMP-I [Q92031.1] from A. contortrix laticinctus, and ApIVMP-I [B7U492.1] from A. piscivorus } \\
\text { leucostoma. The \% identity is shown in the figure }\end{array}$} \\
\hline
\end{tabular}

class) [P83512.2] from B. asper, atrolysin-c [Q90392.1] from $C$. atrox with $76.3 \%$ identity, and was $74.8 \%$ identical to AclVMP-I [Q92031.1] from Agkistrodon contortrix laticinctus and AplVMPI [B7U492.1] from A. piscivorus leucostoma (Fig. 3). In addition, $\mathrm{BC} 02$ (0.3 \% of total toxins) were homologous to a non-hemorrhagic MP-II (BjussuMP-II) from B. jararacussu venom gland. According to Marcussi et al. [49], BjussuMP-II isolated from $B$. jararacussu snake venom belongs to class P-I devoid of hemorrhagic activity, but exhibit proteolytic activity on some components of the extracellular matrix proteins such as fibrinogen, collagen, and gelatin. Additionally, several non-hemorrhagic P-I SVMPs with fibrino(geno) lytic activity have been reported in Bothrops species such as colombienase- 1 and colombienase- 2 from $B$. colombiensis [2], BJ-PI2 from B. jararaca [50], and neuwiedase from $B$. neuwiedi [51].
The BC03 belongs to the P-II metalloproteinases and are all $5^{\prime}$-truncated transcripts with a region of $\mathrm{Zn}^{2+}$ binding site and RGD-disintegrin domain, a main integrin receptor-binding motif. We compared the RGDdisintegrin region of the representative clone [JZ880095] with other closely related medium-sized disintegrins, which was a homolog to Jararin [Q0NZX6.1] from B. jararaca, r-Cam-dis [J9Z332.1] from C. adamanteus, salmosin-3 [O93515.1] from Gloydius brevicaudus, viridistatin [AEY81222.1] from C. viridis viridis, mojastin 2 isolated from the venom of $C$. scutulatus scutulatus, the native disintegrin colombistatin [P18618.2] from B. colombiensis with 93, 89, 85, 79, 76, and $71 \%$, respectively (Fig. 4). A singleton $\mathrm{BC} 04$ is a partial sequence with an RGD motif and had $95.7 \%$ identity with the RGD-disintegrin domain of a metalloproteinase identified in the cDNA library from the venom gland of G. ussuriensis [52]. 


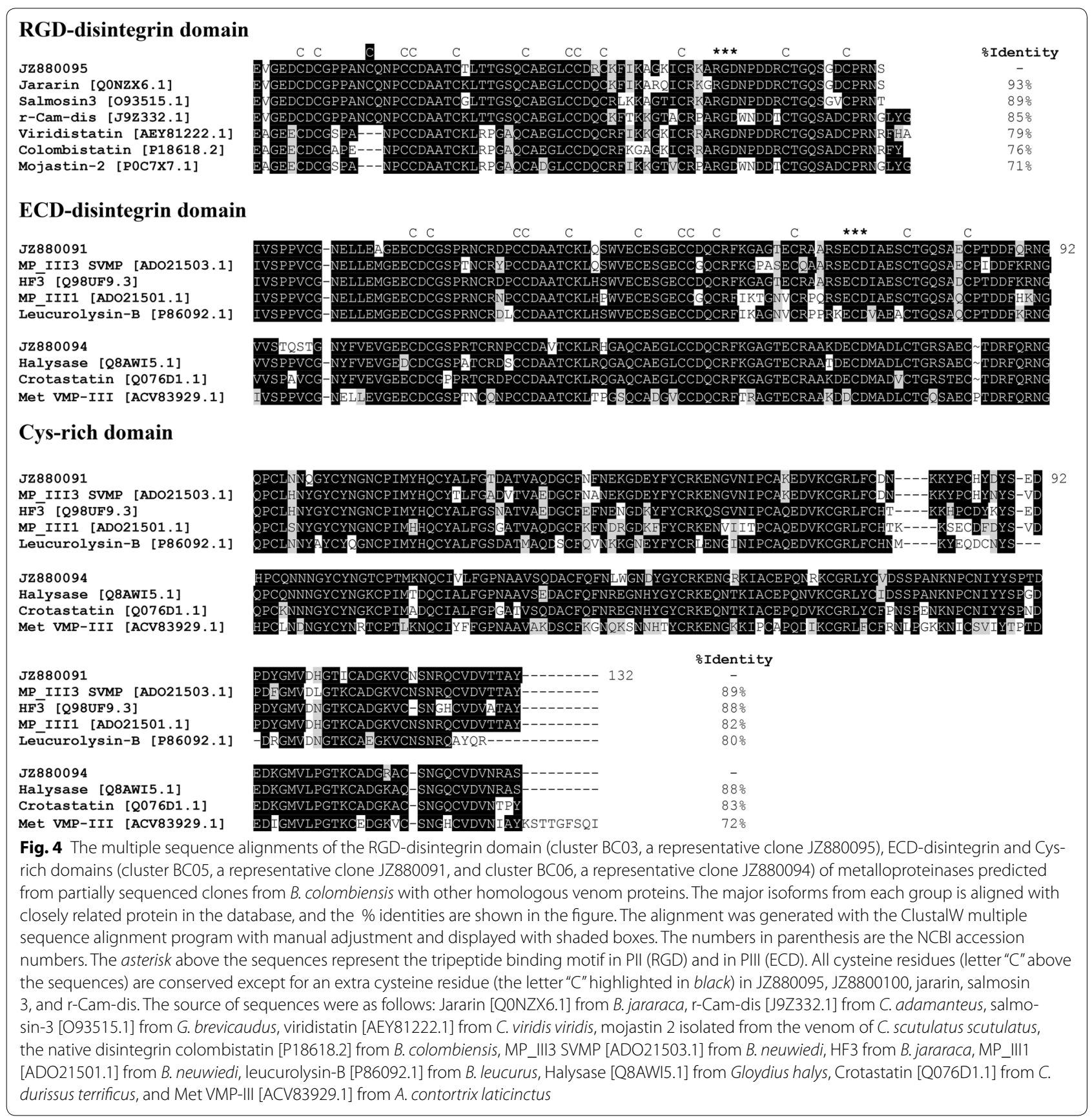

The clusters $\mathrm{BC} 05-\mathrm{BC} 10$ are all class P-III metalloproteinases containing $\mathrm{Zn}^{2+}$ binding motifs, the diversity among PIII isoforms disintegrin-like (D/SECD motif), and cysteine-rich domains. We also compared the deduced amino acid sequences from the ECD-disintegrin and Cys-rich domains (Fig. 4). High partial sequence identity (72-89\%) was observed between the major isoforms from the most abundant PIII-SVMP clusters BC05 [JZ880091] and BC06 [JZ880094] and were compared with other viperid SVMPs (Fig. 4).
In the venom-gland transcriptome of $B$. colombiensis, there is a large quantity of class P-I SVMPs (with some of P-III and few P-II SVMPs), contributing to its moderate venom toxicity [1-3], which is relative to the snake's large size and high production of venom. Our expression profile of SVMPs is in accordance with the proteomic studies as previously reported by Calvete et al. [11] (Table 3), which demonstrated that the P-I SVMPs (30.8\% of total toxins) were the major proteins expressed in the venom of B. colombiensis with few P-III (11.3\%). 
Table 3 The proportional representation of each B. colombiensis venom protein family as predicted from the venom grand transcriptome (this study) and venom proteomics as previously reported by Calvete [11]

\begin{tabular}{lcc}
\hline Protein family & $\begin{array}{l}\text { \% Total venom gland pre- } \\
\text { dicted toxin transcripts }\end{array}$ & $\begin{array}{l}\text { \% Total venom } \\
\text { proteins }\end{array}$ \\
\hline Metalloproteinase & 37.5 & 42.1 \\
PI & 31.4 & 30.8 \\
PII & 0.9 & - \\
PIII & 5.2 & 11.3 \\
PLA 2 & 29.7 & 44.3 \\
PLA $_{2}$-K49 & 20.9 & 34.1 \\
PLA $_{2}$-D49 & 8.7 & 10.2 \\
Serine proteinase & 11.9 & $<1$ \\
WAP & 5.5 & - \\
C-type lectin & 4.1 & - \\
Nucleotidases & 3.2 & - \\
CRISP & 2.3 & 0.1 \\
SVVGF & 2.3 & - \\
LAO & 2 & 5.7 \\
BPP/C-NP & 0.9 & 0.8 \\
Phospholipase B & 0.6 & - \\
Medium disintegrin & - & 5.6 \\
DC fragment & - & 0.5 \\
\hline
\end{tabular}

a Disintegrin-like/cysteine-rich fragment

No P-II SVMPs were detected by proteomic analysis, however, a medium-sized disintegrin (5.6 \%) was found and was similar to colombistatin (RGD-disintegrin) as previously reported by Sánchez et al. [46]. The absence of P-II SVMPs with few disintegrins and disintegrinlike/cysteine-rich (DC) domain of P-III SVMPs in snake venom protein but not in our transcriptome, it could be due to the post-translational processing of disintegrin domain and DC fragment from its precursor form of the P-II and P-III classes, respectively [38, 53, 54].

In our group, there have been substantial commitments to propose venom metalloproteinases and disintegrins as therapeutic agents acting on hemostasis $[1-3,8,46$, 55-61]. Because of proteomic limitations, the development of cDNA libraries could expedite the use of snake venom metalloproteinases and disintegrins as therapeutics against thrombus formation.

\section{Phospholipases $A_{2}\left(P L A_{2}\right)$}

Phospholipase $\mathrm{A}_{2}\left(\mathrm{PLA}_{2}\right)$ is one of the major components in Viperidae snake venoms responsible for the induction of local tissue damage. PLA $\mathrm{P}_{2}$ enzymes are known to exhibit distinct pharmacological effects, such as local myonecrosis, lymphatic vessel damage, cytotoxicity, anticoagulant, hemolysis, and hemorrhage [62, 63].

$\mathrm{PLA}_{2}$ (29.7\% of total toxins) was the second most highly expressed toxin component of the $B$. colombiensis transcriptome. In general, after B. jararacussu [64], the observed $\mathrm{PLA}_{2}$ transcript abundance from B. colombiensis is one of the highest described thus far, greater than that reported for B. asper (14.2-17.8\%), B. atrox (13.3\%), B. jararaca (0.7-9.5\%), B. insularis (6.7\%), and B. alternatus (urutu) (5.6 \%) (Fig. 2; Additional file 3) [24-26, 64, 65].

In our database, we obtained two clusters (BC11 and $\mathrm{BC13)}$ with full coding sequences and one singleton (BC12). The BC11 showed $100 \%$ similarity to basic PLA 2 myotoxin II [P24605.3] of $B$. asper with a lysine (Lys) at position $49\left(\mathrm{PLA}_{2}-\mathrm{K} 49\right)$ at the catalytic site, which is commonly found in Bothrops species (Fig. 5a, c). The $\mathrm{BC} 13$ showed an aspartic acid (Asp) in the same position $\left(\mathrm{PLA}_{2}-\mathrm{D} 49\right)$ and was matched with an acidic $\mathrm{PLA}_{2}$, BmooPLA $_{2}$ [G3DT18.1] of B. moojeni with $87.7 \%$ of similarity (Fig. 5b, c). The PLA $\mathrm{P}_{2}-\mathrm{K} 49$ was more than twofold abundant than the $\mathrm{PLA}_{2}$-D49 (Table 3). This observation corresponded to the proteomic profile reported by $\mathrm{Cal}-$ vete et al. [11].

Interestingly, we found one transcript (BC12) with a $5^{\prime}$ truncated sequence sharing $96.5 \%$ similarity with a basic PLA P $_{2}$ motoxin III [P20474.2] from $B$. asper, and its deduced amino acid sequence showed the Asp49 residue (Fig. 5c). Although two basic Asp49 $\mathrm{PLA}_{2}$ s have been isolated from $B$. jararacussu (BthTX-II) and B. pirajai (PrTX-III), both exhibiting a myotoxic effect [66-68], this is the first basic Asp49 PLA 2 found in B. colombiensis. However, the proteomic work done by Calvete et al. [11] on this same species did not identify this toxin.

\section{Serine proteinases}

Serine proteinases are abundant and widely distributed in snake venoms and interfere mainly with the hemostatic system [69-71]. We identified two unique, full-length

(See figure on next page.)

Fig. 5 cDNA and deduced amino acid sequences of a representative clone PLA - K49 from cluster BC11 [dbEST: JZ880101] (a) and a representative PLA $A_{2}$-D49 clone from cluster BC13 [dbEST: JZ880102] (b). The 16-residue signal peptide is underlined. The mature sequence is bolded. (c) Multiple alignments of predicted amino acid sequences of PLA $2-K 49, P L A_{2}-D 49$, and basic D49-PLA 2 with other homologous venom proteins. The alignment was generated with the ClustalW multiple sequence alignment program with manual adjustment and displayed with shaded boxes. PLA - K49 [dbEST: JZ880101] is identical to basic the PLA 2 homolog 2 (myotoxin II) from B. asper. Basic D49-PLA 2 [dbEST: JZ880106] had 96.5 \% identity to basic PLA $A_{2}$ myotoxin III [P20474.2] from B. asper. PLA $A_{2}$-D49 [dbEST: JZ880102] is closely homologous to BmooPLA from B. moojeni. The numbers in parenthesis are the NCBI accession numbers 


\section{a PLA $\mathbf{2}-$ K49 [JZ880101]}

\section{5' untranslated region}

1 cggggtctgctcattcccaggtctgaatttgggaggatgaggactctctggataatggec 60

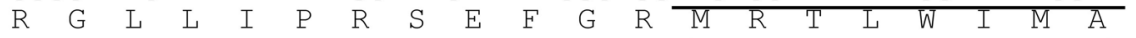

61 gtgttgctggtgggcgtcgaggggagcctgtttgaat $\overline{\text { tggggaagatgatcctgcaaga }} 120$

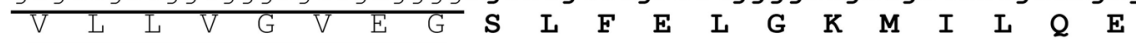

121 acggggaaaaccctgctaaatcctacggtgcttatggatgcaactgtggcgtgttaggc 180 $\begin{array}{lllllllllllllllllllll} & T & G & K & N & P & A & K & S & Y & G & A & Y & G & C & \text { N } & C & G & \text { V } & \text { L } & G\end{array}$

181 cgaggcaagccaaaggacgccactgaccgctgctgctacgtgcacaaatgctgttacaaa 240 $\begin{array}{llllllllllllllllllll}R & G & K & P & K & D & A & T & D & R & C & C & Y & V & H & K & C & C & Y & K\end{array}$

241 aaactgaccggctgcaaccccaaaaaggaccgctactcctatagctggaaggacaagact 300 $\begin{array}{llllllllllllllllllll}K & L & T & G & C & N & P & K & K & D & R & Y & S & Y & S & W & K & D & K & T\end{array}$

301 atcgtctgcggagagaacaactcatgcctgaaggagttgtgtgagtgcgacaaggccgtg 360 $\begin{array}{llllllllllllllllllll}I & V & C & G & E & N & N & S & C & L & K & E & \text { L } & C & E & C & D & K & A & V\end{array}$

361 gcaatctgcctccgagaaatctgaacacgtacaacaaaaatataggtattacctgaaa 420 $\begin{array}{llllllllllllllllllll}A & I & C & L & R & E & N & L & N & T & Y & N & K & K & Y & R & Y & Y & L & K\end{array}$

421 cctctttgcaagaaggcagatgcatgttaa 450

$\begin{array}{llllllllll}P & L & C & K & K & A & D & A & C & *\end{array}$

b PLA 2 -D49 [JZ880102]

5' untranslated region

1 cggggtctgtccattcccaggtctggattcaggaggatgaggattctctggataatggtc 60 $\begin{array}{lllllllllllllllllllll}R & G & L & S & I & P & R & S & G & F & R & R & M & R & I & L & W & I & M & V\end{array}$

61 gtgttgctggtgggcgtcgaggggaacctgtggcaat ttgagatgttgatcatgaaaatt 120 $\begin{array}{llllllllllllllllllllllll}V & \mathrm{~L} & \mathrm{~L} & \mathrm{~V} & \mathrm{G} & \mathrm{V} & \mathrm{E} & \mathrm{G} & \mathbf{N} & \mathbf{L} & \mathbf{W} & \mathbf{Q} & \mathbf{F} & \mathbf{E} & \mathbf{M} & \mathbf{L} & \mathbf{I} & \mathbf{M} & \mathbf{K} & \mathbf{I}\end{array}$

121 gegaagacaagtggttttatgttctacagctcttacggatgctactgcggctgggggggc 180 $\begin{array}{llllllllllllllllllll}A & K & T & S & G & F & M & F & Y & S & S & Y & G & C & Y & C & G & \text { W } & G & G\end{array}$

181 catggccggcctcaggacgccagtgaccgctgctgctttgtgcacgactgctgttatgga 240 $\begin{array}{llllllllllllllllllll}H & G & R & P & Q & D & A & S & D & R & C & C & F & V & H & D & C & C & Y & G\end{array}$

241 aaagtgaccggctgcaacccaaaattcgacacctacacctacagcgaggagaacggggtt 300 $\begin{array}{llllllllllllllllllll}K & V & T & G & C & N & P & K & F & D & T & Y & T & Y & S & E & E & N & G & V\end{array}$

301 gtcgtctgcggaggggacgacccgtgcaagaagcagatttgtgagtgtgacagggttgcg 360

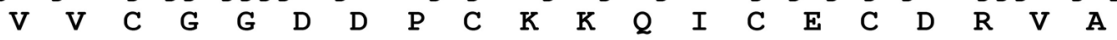

361 gcaacctgcttccgagacaataaggacacatacgacagtaaatataagcgtttcccggcc 420 $\begin{array}{llllllllllllllllllll}A & T & C & F & R & D & N & K & D & T & Y & D & S & K & Y & K & R & F & P & A\end{array}$

421 gaaaattgccaggaggagtcagagccatgctaagtctctgcaggccgggaaaaacccctc 480 $\begin{array}{lllllllllll}E & N & C & Q & E & E & S & E & P & C & *\end{array}$

C

JZ880101

Myotoxin II [P24605.3]

JZ880106

Myotoxin III [P20474.2]

JZ880102

BmooPLA 2 [G3DT18.1]

JZ880101

Myotoxin II [P24605.3]

JZ880106

Myotoxin III [P20474.2]

Jz880102

BmoOPLA 2 [G3DT18.1]
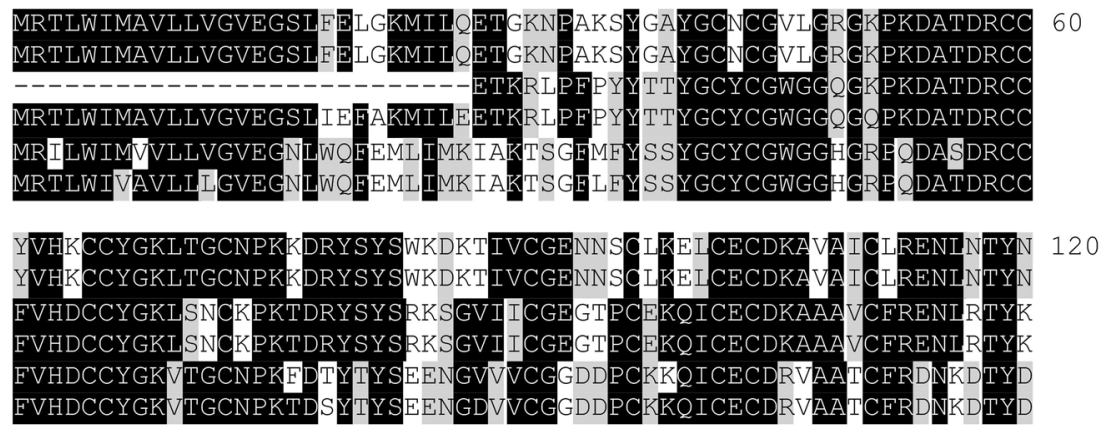

JZ880101

Myotoxin II [P24605.3]

JZ880106

Myotoxin III [P20474.2]

JZ880102

$\mathrm{BmOOPLA}_{2}$ [G3DT18.1]
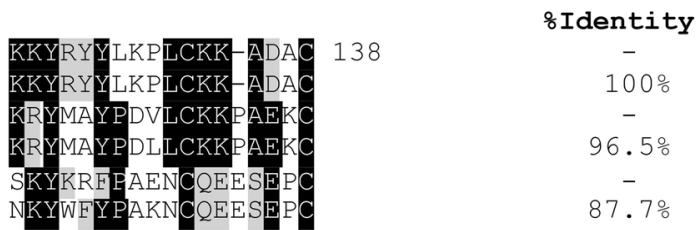


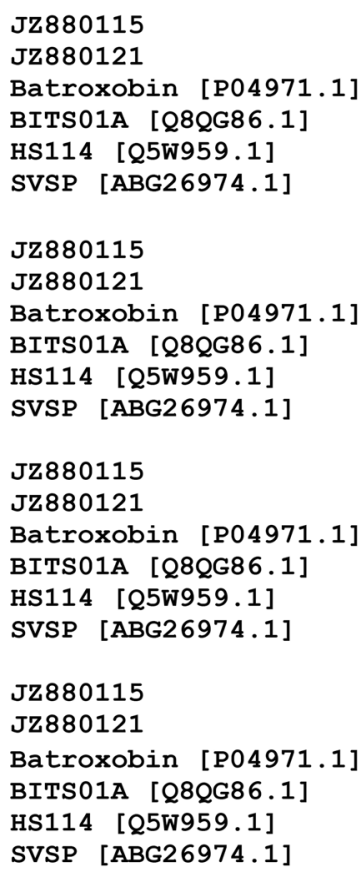

Fig. 6 The multiple alignments of completed predicted amino acid sequences of the major isoforms of each cluster BC14 [JZ880115] and BC15 [JZ880121] with batroxobin [P04971.1] from B. atrox, BITS01A [Q8QG86.1] from B. insularis, HS114 [Q5W959.1], HS114 [Q5W959.1] from B. jararaca, and SVSP [ABG26974.1] from Sistrurus catenatus edwardsii. Residues forming the catalytic triad are highlighted with a dark background

MVLIRVIANLLILQVSYAQKSSELVIGGDECDINEHPFLAFMYYSPRYFCGMTLINKEWVLTAAHCNRRF 70 MVLVRVVANLLILQLSYAQKA.SELVVGGDECNINEHRSLVAIFNSTGFFCSGILLNQEWVLTASHCDSTN MVLIRVIANLI ILQVSYAQKS SELVIGGDECDINEHPFLAFMYYSPRYFCGMTLINQEWVLTAAHCNRRF MVLIRVIANLLILQVSYAQKSSELVVGGDECDINEHPFLAFLY-SHGYFCGLTLINQEWVLTAAHCDRRF MVLVRVVANLLILQLSYAQKVSELVVGGDECNINEHRSLVAIFNSTGFFCSGILLNQEWVLTASHCDSTN MVLIRVLATLIILQLSYAQKSSELVVGGRPCNINEHRSLVVLFNSSGFLCAGTLINQEWVLTAAHCDIKN

MRIYVGIHARSVANDDEVIRYAKEKFICPNKKKNVITDKDIMLIRLNRPVKNSEHIAPLSLPSNPPSVGS 140 FQMKIGVHSKKSLNQDEQTRNPKEKIFCPNKKNDDALDKDLMLVRLDSPVSNSEHIAPLSLPSSPPSVGS MRIHLGKHAGSVANYDEVVRYPKEKF ICPNKKKNVITDKDIMLIRLDRPVKNSEHIAPLSLPSNPPSVGS MRIYLGI HARSVANDDEVIRY PKEKFICPNKNMSDEKDKDIMLIRLNRPVKNSTHIAPISLPSNPPSVGS FQMKIGVHSKKTLNQDEQTRNPKEKIFCPNKKNDDALDKDLMLVRLDSPVSDSEHIAPLSLPSSPPSVGS FQIQLGVHSKKVRNEDEQTRDPREKFFCLGSKTNNEWEKDIMLIRLNNPVSNSAHIAPLSLPSSPPSVGS

VCRIMGWGAITTSEDTYPDVPHCANINLFNNTVCREAYNGLPAK--TLCAGVLQGGIDTCGGDSGGPLIC 210 VCRIMGWGS ITPIAKTNPDVPHCANINLLDDAVCRAAYPELPAEYRTLCAGVLEGGIDTCNGDSGGPLIC VCRIMGWGAITTSEDTYPDVPHCANINLFNNTVCREAYNGLPAK--TLCAGVLQGGIDTCGGDSGGPLIC VCRVMGWGS ITI PNDTYPDVPHCAN INLVNDTVCRGAYKRFPAKSRTLCAGVLQGGKDTCVGDSGGPLIC VCRIMGWGS ITPIQKTNPDVPHCAN INLLDDAVCRAAY PELPAEYRT LCA GVPEGG I DTCNGDSGGPLIC LCRIMGWGT ISSTKE I Y PNVPRCAN INI LDYAVCRAAYPWWPVTTRILCAGI LEGGKDSCQGDSGGPLIC

NGQFQGILSWGSDPCAEPRKPAFYTKVFDYLPWIQSIIAGNKTATCP- 258

NGQFQGIVFYGAHPCGQAPKPGLYTKVIDYNTWIESVIAGNTAATCPP

NGQFQGILSWGSDPCAEPRKPAFYTKVFDYLPWIQSIIAGNKTATCP-

NGTFQGIVSWGGKVCARPRKPALYTKVFDYLPWIQSIIAGNKTATCPP

NGQFQGIVFYGAHPCGQAPKPGLYTKVIDYNTWIESVIAGNTAATCPP

NGEIQGIVSWGAHPCGRRLNPGFYTKVFDYIDWIQSITAGNTTVTCPQ serine proteinases in the cDNA library of B. colombiensis and were denoted $\mathrm{BC} 14$ and $\mathrm{BC} 15$. The $\mathrm{BC} 14$ was a major serine proteinase cluster (39 ESTs, $11.3 \%$ of total toxins) sharing $83.9 \%$ identity with thrombin-like enzyme batroxobin from B. atrox. The BC15 (2 ESTs, $0.6 \%$ of total toxins) shared a slight similarity (69.6\%) to snake venom serine protease, HS114, from $B$. jararaca. The complete coding sequences of representative clones JZ880115 and JZ880121 from clusters BC14 and $\mathrm{BC} 15$; respectively, ranged from 255 to 258 amino acids in length, containing a trypsin-like serine proteinase domain with highly conserved functional residues of the catalytic triad (His41, Asp86, and Ser178 for BC14 and Ser180 for BC15) (Fig. 6). The putative identity matches for each representative clone is shown in Additional file 2 .

Overall, they accounted for $11.9 \%$ of the toxin transcripts, which is at least twofold more expressed than that of any other components of the remainder toxin genes in this snake. The abundance of these genes is high among the genus Bothrops transcriptomes presented in the literature, and comparable, for example, to the $8.3 \%$ reported in Pacific B. asper [65] and $8.1 \%$ in B. atrox [25], respectively (Fig. 2; Additional file 3). Our results are also similar to the recently described transcripts for B. jararaca $(8.1 \%)$ by Zelanis et al. [26]. However, older data published by Cidade et al. [27] for B. jararaca, indicates
$28.5 \%$ for serine proteinase. Other species of Bothrops express considerably less serine proteinase transcripts than B. colombiensis, e.g. B. jararacussu (2.4\%) and B. alternatus (urutu) (1.9\%) [24, 64].

\section{Other less-abundance toxins}

The principal venom components of the B. colombiensis transcriptome are metalloproteinases, $\mathrm{PLA}_{2}$, and serine proteinases, ranging from 12 to $38 \%$ of the total toxin ESTs. The remainder of the results (the highest expressed is less than $6 \%$ ) was categorized in "other less-abundance toxins" because they vary from a relative moderate to low expression level (Table 1).

\section{Waprin}

From this group of transcripts, Waprin is found to be very interesting. In general, waprin is a small protein containing 50 amino acid residues. This protein belongs to the Whey acidic protein (WAP) family due to its fourdisulfide core domain structure. The WAP domain is found in proteins which are highly divergent regarding a broad range of biological functions involving the innate immune system, regulating cell proliferation, and inhibiting various cellular proteins [72, 73]. The function of waprin in snake venom is unknown. Only one waprin from Oxyuranus microlepidotus venom has been examined, and it was shown to act as an antimicrobial [72]. 


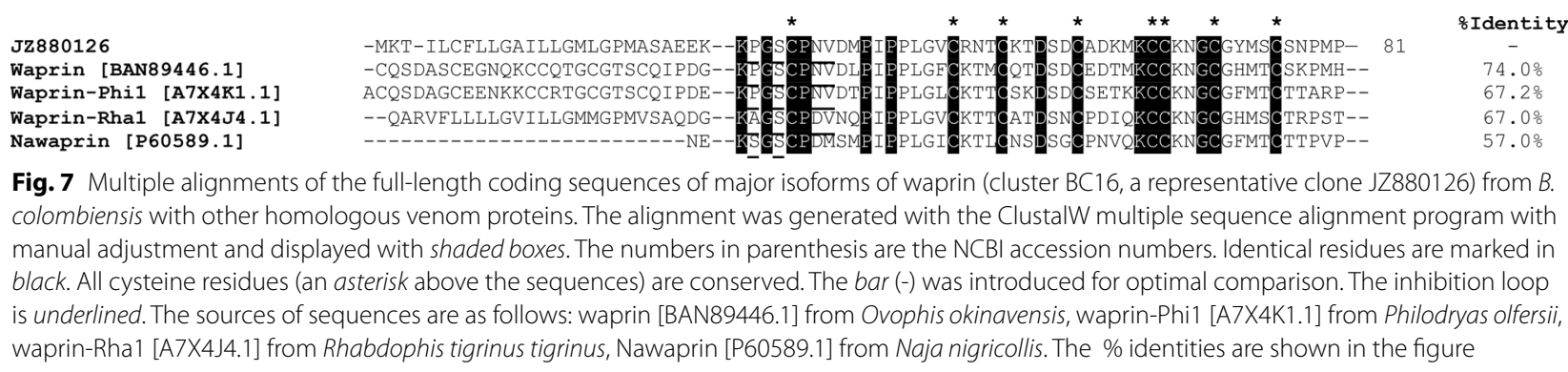

Fig. 7 Multiple alignments of the full-length coding sequences of major isoforms of waprin (cluster BC16, a representative clone JZ880126) from B. colombiensis with other homologous venom proteins. The alignment was generated with the ClustalW multiple sequence alignment program with manual adjustment and displayed with shaded boxes. The numbers in parenthesis are the NCBI accession numbers. Identical residues are marked in black. All cysteine residues (an asterisk above the sequences) are conserved. The bar (-) was introduced for optimal comparison. The inhibition loop is underlined. The sources of sequences are as follows: waprin [BAN89446.1] from Ovophis okinavensis, waprin-Phi1 [A7X4K1.1] from Philodryas olfersii, waprin-Rha1 [A7X4J4.1] from Rhabdophis tigrinus tigrinus, Nawaprin [P60589.1] from Naja nigricollis. The \% identities are shown in the figure

In this library, 19 waprins were identified and were grouped into 1 cluster named BC16, comprising $5.5 \%$ of total toxins (Tables 1,2). All waprin sequences are full-length coding sequences with a conserved WAP domain and an inhibitory loop. The protein BLAST search and CLUSTAL W multiple sequence alignments revealed that the amino acid sequence of a representative clone JZ880126 of waprin was homologous to waprin [BAN89446.1] from Ovophis okinavensis, waprin-Phi1 [A7X4K1.1] from Philodryas olfersii, waprin-Rha1 [A7X4J4.1] from Rhabdophis tigrinus tigrinus, and Nawaprin [P60589.1] from Naja nigricollis with 74, 67.2, 67 , and $57 \%$ identity, respectively (Fig. 7).

Waprin is very uncommon in venom of Bothrops snakes. Bothrops species express this toxin transcript at a very low level, or even undetectable, but its expression was the fourth most highly expressed transcript in $B$. colombiensis (Additional file 3). In a study of eight snake venom transcriptomes of distinct genera (Crotalus, Bothrops, Atropoides, Cerrophidion, and Bothriechis) from Costa Rica, waprin ESTs were only and barely detected in $B$. asper (0.1\%) individuals from the Caribbean, but not in $B$. asper from the Pacific region [65]. However, waprin seems to be a transcript frequently recovered from venom transcriptomes in other snakes from other snake families such as Elapidaes (Naja nigricollis, $O$. microlepidotus, Acanthophis wellsi, and others), Colubridaes (Thrasops jacksonii), Dipsadidaes (Liophis poecilogyrus and P. olfersii), Homalopsidaes (Enhydris polylepis), and Natricidae (Rhabdophis tigrinus) [74, 75]. This unexpected abundance of waprin genes found in our transcriptome opens new avenues for further investigation.

\section{C-type lectins}

Snake venom C-type lectins (snacles) are commonly found in snake venoms. They affect blood coagulation and platelet function by interacting with some proteins in the blood coagulation system and cell surface receptors, causing an imbalance of the hemostatic system [76].

We obtained three clusters of partial C-type lectins named $\mathrm{BC} 18-\mathrm{BC} 20$ and one singleton (BC21). The
BC18 accounted for $2.3 \%$ of total toxins with $82.7 \%$ similarity to the beta subunit snaclec, bothroinsularin, isolated from B. insularis [77]. Clusters BC19 (0.9 \% of total toxins) and BC20 (0.6\% of total toxins) were 62 and $69.4 \%$ identical to C-type lectin beta-subunit from Ovophis okinavensis and from Protobothrops elegans, respectively. The complete sequence $(\mathrm{BC} 21)$ showed $77.4 \%$ identity to C-type lectin F IX/X B from Protobothrops flavoviridis. The deduced amino acid sequence contained 146 amino-acid residues with a carbohydrate-recognition domain and highly conserved seven cysteine residues.

In total, C-type lectins transcripts accounted for $4.1 \%$ of the total toxins, which was higher than that of $B$. alternatus (1.4\%), B. asper Pacific (1.3\%) and Caribbean (1\%). However, its abundance was considerably less than in B. insularis (14.2-14.5\%), B. jararaca (8.3-22.3\%), B. jararacussu (7.4 \%), and B. atrox (6.6 \%) (Fig. 2; Additional file 3) [24-27, 64, 65, 78].

\section{Nucleotidase}

Nucleotidases ( $5^{\prime}$ nucleotidase, ADPase, ATPase, and phosphodiesterase) are hydrolytic enzymes found in snake venoms that have an important role in the releasing of adenosine from nucleic acids $[79,80]$. The generation of adenosine, a multitoxin, could interfere with different biological activities such as inhibiting platelet aggregation, inducing the diffusion of toxins by increasing vascular permeability through vasodilation, and immobilization of prey by depletion of ATP [80-83].

We obtained one cluster (BC22) of ATPase (9 ESTs, $2.6 \%$ of total toxins) and a singleton (BC23, $0.3 \%$ of total toxins). They matched with ATPase six from $A$. piscivorus and V-type proton ATPase subunit e 1 from Ophiophagus hannah, and the similarity scores were 79.2 and $96.3 \%$, respectively. We also found a singleton (BC32, $0.3 \%$ of total toxins) encoding a phosphodiesterase, which showed $81 \%$ identity with a phosphodiesterase from Ovophis okinavensis. Several transcriptomic and proteomic studies reported the expression of these toxins in various snakes $[24,65,84-88]$. However, the function of these enzymes during envenomation remains unclear. 


\section{Cysteine-rich secretory proteins (CRISP)}

Eight ESTs sequences of the cysteine-rich secretory proteins (CRISP) were recovered from the B. colombiensis cDNA library. CRISP proteins are an evolutionarily conserved family, which possess 16 highly conserved cysteine residues, 10 of these cysteines are located in the carboxyl-terminal third end. These proteins have been found in the mammalian male reproductive tract and in snake venoms and salivary extractions [89-91].

One major CRISP cluster named BC24 (7 ESTs, $2 \%$ of total toxins) and one singleton (BC25, $0.3 \%$ of total toxins) were identified. The complete coding sequence of BC24 showed $83.7 \%$ identity with a partial cysteine-rich venom protein from $P$. flavoviridis. The $B$. colombiensis homolog was 258 amino acids in length and contained two conserved domains including a sperm-coating protein (SCP)-like extracellular protein domain with $\mathrm{N}$-terminal pathogenesis-related protein-1 (PR-1) domain and a C-terminal cysteine rich domain (CRD) with 10 conserved cysteine residues. The singleton $\mathrm{BC} 25$ was homologous to a cysteine-rich protein 1 from $O$. hannah with $98.7 \%$ identity. Its deduced amino acid sequence consisted of a 54-residue LIM (lin-11-isl-1-mec-3) domain containing two zinc finger motifs with eight conserved residues, seven cysteines and one histidine.

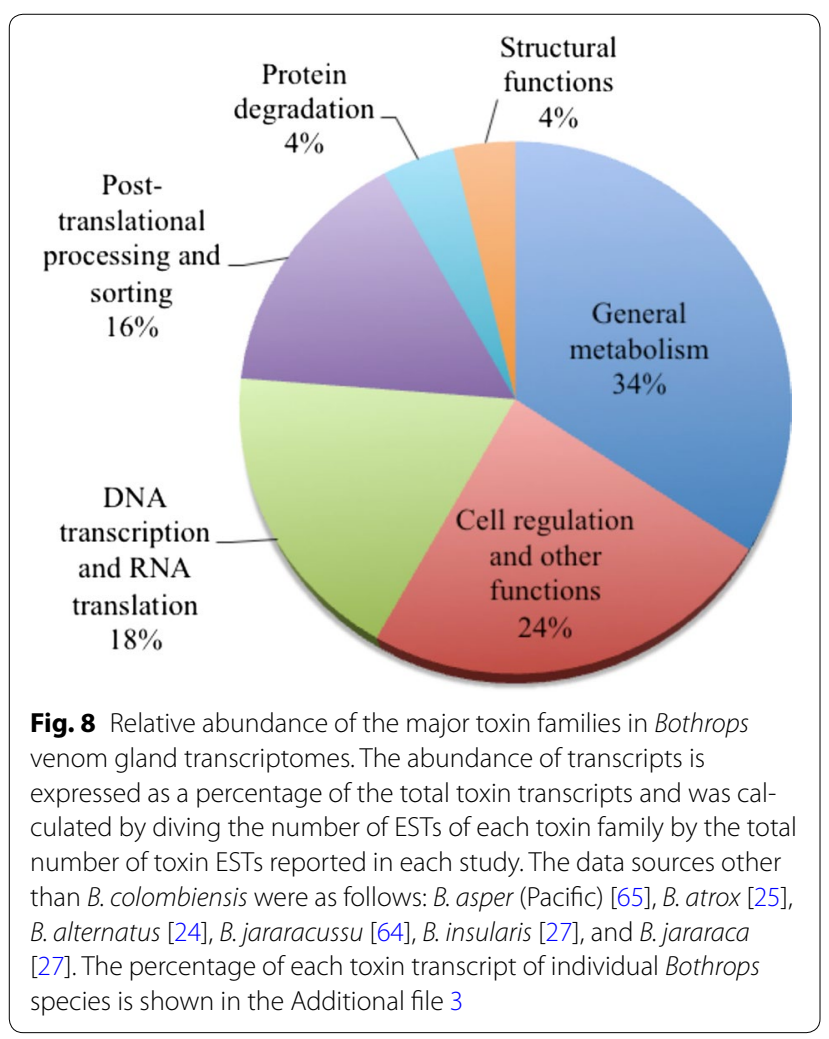

CRISPs represent the seventh most abundant toxin transcript in B. colombiensis venom, $2.3 \%$ of the whole toxin genes. This is one of the highest reported in the literature. The values are under $1 \%$ for $B$. alternatus, $B$. atrox, and $B$. asper. While B. jararacussu (1\%), B. insularis (0.6-1.5 \%), and B. jararaca (1-1.6\%) expressed values over this cutoff (Fig. 2; Additional file 3) [24-27, $64,65,78]$. Interestingly, the only comparable values to our findings are the CRISP transcript level described in the newborn venom glands from B. jararaca (2.7 \%), which is about two or threefold higher than that of adult [26].

Although the CRISP family is widely distributed in snake venoms, there is scarce information about its contribution to the pathology of snakebites. A CRISP protein from Philodryas patagoniensis snake venom was described to cause myonecrosis in a murine model [92]. Recently, Estrella et al. [89] isolated a CRISP protein, helicopsin, from the broad-banded water snake (Helicops angulatus), which has been shown to exhibit neurotoxic activity causing rapid death in mice. In general, CRISP proteins are thought to interfere with smooth-muscle contraction by interfering with the $\mathrm{Ca}^{2+}$ and $\mathrm{K}^{+}$channels $[75,93]$. An effort needs to be done to improve the knowledge of this toxin. On the other hand, these proteins are attractive as therapeutics, as ion channel modulators represent a high potential as pharmacological agents.

\section{Snake venom vascular endothelium growth factor (svVEGF)}

svVEGFs have been found in Bothrops species and act as mediators of vascular permeability, which may be involved in the absorption of venom toxins and hypotension during envenomation $[94,95]$. We found only one cluster (BC26 with 8 ESTs, $2.3 \%$ of total toxins) encoding for svVEGF. The BC25 was homologous to a svVEGF from $B$. insularis with $95.2 \%$ similarity. The abundant of svVEGF was less represented than in B. insularis (4.3$4.7 \%$ ) but higher than in $B$. atrox (0.9\%), B. alternatus $(0.6 \%)$ and $B$. jararaca (0.2-1.5 \%) (Fig. 2; Additional file 3) [24-27, 78].

\section{L-amino oxidase (LAO)}

LAOs are widely distributed in snake venoms and are responsible for diverse biological activities including hemorrhage, edema, alterations in blood coagulation, activation or inhibition of platelet aggregation, apoptosis, and cytotoxicity [96]. The abundance of LAO transcripts presented in the Bothrops venom gland transcriptomes ranges from 0.5-4.2 \% (Fig. 2; Additional file 3) [24-27, 64, 65, 78]. In our EST database, LAO accounted for $2.03 \%$ of total toxins, consisting of one cluster (BC27, 6 ESTs) and one partial singleton (BC28). The $\mathrm{BC} 27$ 
and BC28 had 92.8 and $94 \%$ amino acid similarities to the L-amino-acid oxidase of B. pauloensis and Cerastes cerastes, respectively.

\section{Bradykinin-potentiating and C-type natriuretic peptide (BPP/C-NP)}

Bradykinin-potentiating peptides (BPPs) are well known to be inhibitors of the angiotensin-converting enzyme and may contribute to venom-induced hypotension [97]. C-type natriuretic peptides (C-NPs) also play a significant role in vascular and cardiac function [98]. Several studies have reported the presence of BPPs/C-NP in snake venom gland, spleen, pancreas, and brain $[99,100]$.

We identified three partial transcripts encoding BPP/C$\mathrm{NP}$ in the B. colombiensis venom gland library $(0.9 \%$ of toxin ESTs, BC29) that shared $86 \%$ similarity with a partial BPP/C-NP from P. flavoviridis. The percentage of $\mathrm{BPP} / \mathrm{C}-\mathrm{NP}$ transcripts was particularly very low, one of lower reported in the literature (Fig. 2; Additional file 3). The proportion of this gene in venom toxin of Bothrops transcriptomes is $6-23 \%[19,24,26,27,65,78]$.

\section{Phospholipase B}

We detected two partial individual singletons encoding phospholipase $\mathrm{B}$ (BC30 and BC31), which were 93.1 and $96.9 \%$ identical with phospholipase B from P. flavoviridis and C. adamanteus, respectively. The phospholipase $\mathrm{B}$ accounted for $0.6 \%$ of the toxin-related genes in the B. colombiensis transcriptome. Phospholipase B toxins have been documented in the transcriptomes of $C$. adamanteus [86] and B. atrox [25]; however, these toxins in $B$. atrox were grouped as a cellular transcript (Fig. 2; Additional file 3). Phospholipases B were also found in the proteomes of $C$. adamanteus [101], C. viridis viridis [102], B. jararaca, B. atrox, B. jararacussu, B. neuweidi, $B$. altenatus, and B. cotiara [103], and Australian elapid snake, Pseudechis guttatus [104]. This molecule could be responsible for the hemolytic activity as previously described in several Australian elapid venoms [105-108].

\section{Identification of cellular transcripts}

The non-toxin transcripts (160 transcripts) were composed of $22 \%$ of the B. colombiensis venom gland. They are categorized into 6 groups according to their biological processes (Fig. 8). The most abundant transcripts coding for metabolic enzymes were related to general metabolism (34.4\% of cellular transcripts and $7.5 \%$ of total transcripts), such as cytochrome c oxidase (21 ESTs, $2.9 \%$ of total transcripts), cytochrome b (11 ESTs, $1.5 \%$ of total transcripts), NADH dehydrogenase (7 ESTs, $1 \%$ ). These transcripts are commonly found in snake venom glands $[19,27,88]$. Transcripts related to cell regulation and other functions comprised $23.8 \%$ of cellular transcripts
(5.2\% of total transcripts), followed by the DNA transcription and mRNA translation ( $18.1 \%$ of cellular transcripts and $4 \%$ of total transcripts). Among transcripts for DNA transcription and mRNA translation, we identified mostly ribosomal proteins (11 ESTs, $1.5 \%$ of total transcripts) and elongation factors (5 ESTs, $0.7 \%$ of total transcripts).

The post-translational processing and sorting-related transcripts were accounted for $15.6 \%$ of cellular transcripts and $3.4 \%$ of total transcripts. The most abundant transcripts were parvalbumin (5 ESTs composing only one cluster, $0.7 \%$ of total transcripts), which are calciumbinding proteins belonging to EF-hand protein family. The deduced amino acid sequence of parvalbumin was 97.3 \% identical to parvalbumin from C. oreganus helleri and had an EF-hand domain with eight highly conserved residues for calcium-binding. We also found one transcript of another calcium binding protein, calnexin. These calcium-binding proteins may be involved in the process of toxin secretion [19, 109]. Other two low abundant house-keeping genes (each $4 \%$ of cellular transcripts) involved in protein degradation including ubiquitin (6 ESTs) and proteasome (1 EST) and six transcripts related to structural functions such as myosin, tubulin, and collagen also were identified.

\section{Comparison of the transcriptome and proteome of $B$. colombiensis}

A proteomic study of $B$. colombiensis was recently published [11], and this allows us to compare the different toxin occurrences between the transcriptome of this current study and proteome of this snake species. It has to be kept in mind that the transcripts are not necessarily synonymous with the protein expression due to regulatory events presents in the translation process from the mRNA to protein. Additionally, the transcriptomic and proteomic approaches, due to their particular methodologies, may favor the presences or absence of a determinate gene or protein. Moreover, the venom used for the proteomic approach was pooled from the Venezuelan regions of Santa Barbara (Barinas State), San Felipe (Yaracuy State), Barlovento and Araira (Miranda State), while the venom glands of a single $B$. colombiensis snake was used for transcriptomic analysis in this study. For these reasons, our integrated comparison of transcriptomic and proteomic data revealed the quantitative differences between the relative occurrences of protein families in the venom gland transcriptome (expressed as a relative number of transcripts) and venom proteome (expressed as the percentage of total HPLC separated proteins) of $B$. colombiensis (Table 3).

The best match was for BPP/C-NP where transcripts and proteins obtained were very similar (Table 3 ). CRISP 
presents equally low expression for both protein and gene (0.1 vs. $2.3 \%$, respectively). Metalloproteinase and PLA 2 show reasonable agreement between the transcriptome and proteome data. The venom components reported in the proteomic analysis was slightly higher than the transcriptome data for metalloproteinases ( 42.1 vs. $37.5 \%$, respectively) and moderate for $\mathrm{PLA}_{2}$ (44.3 vs. $29.7 \%$, respectively). The same was true for the acidic and basic PLA 2 subclasses: PLA $-\mathrm{K} 49$ (34.1 vs. $20.9 \%$, respectively) and PLA $A_{2}-\mathrm{D} 49$ (10.2 vs. $8.7 \%$, respectively), even the proportion of subclasses $\left(\mathrm{PLA}_{2}-\mathrm{K} 49 / \mathrm{PLA}_{2}-\mathrm{D} 49\right)$ was comparable (3.3-fold for protein vs. 2.4-fold for EST). This was not the case for the third most abundant transcript, serine proteinases comprising of $11.9 \%$, in which the protein component was less than $1 \%$. Such difference between transcriptome and proteome occurrences of serine proteinases has already been observed in B. alternatus [24].

For the first time, we identified waprin in Bothrops spp. transcriptomes, being composed of $6 \%$ of the B. colombiensis venom gland but was not detected using a proteomic approach. In addition, common toxins recognized in snake venoms including C-type lectin and CRISP were found in venom transcriptome, accounting for 4.1 and $2.9 \%$, respectively but was extremely low or undetectable at the protein expression level. These findings showed that the transcriptome and proteome are each other's confirmatory and complementary approaches to the description of B. colombiensis venom.

Symptoms of B. colombiensis envenoming include edema, local tissue damage (ecchymoses, blisters, local hemorrhage, and myonecrosis), and thrombocytopenia with increased risk of systemic bleeding from disseminated intravascular coagulation (DIC), cardiovascular shock, and acute renal failure [110]. In agreement with the clinical observations, the venom composition of B. colombiensis, based on our transcriptomic and proteomic data [11] (Table 3) is heavily dominated by snake venom components affecting hemostasis including SVMPs, PLA 2 , and serine proteinases. The relative contributions of the major toxin classes in the Bothrops snake venom gland transcriptomes revealed the diversity of toxin expression (Fig. 8; Additional file 3). However, the primary toxins including SVMPs, PLA serine proteinases, $\mathrm{BPP} / \mathrm{C}-\mathrm{NP}$, and C-type lectins are likely to be categorized in the most abundant toxin groups in most Bothrops species. These major toxins are responsible for local and systemic effects by inducing hemorrhage (SVMPs), affecting hemostasis (serine proteinases, C-type lectins, disintegrin, and $\mathrm{PLA}_{2}$ ), myonecrosis (myotoxic $\mathrm{PLA}_{2}$ ), and cardiovascular actions (SVMPs, serine proteinases, PLA $\mathrm{A}_{2}, \mathrm{BPP} / \mathrm{C}-\mathrm{NP}$ ) [111-113].

\section{Conclusion}

Snake venoms have a massive impact on human populations through the morbidity and mortality related with snakebites and could also be excellent sources of novel molecules with potential medical applications. In this study, we present the EST database of an individual $B$. colombiensis venom gland, which provides information about the gene expression in a specific specimen and allows a comparative view with the previous proteomic study of this snake. We found many unique toxin sequences, multigene toxin families, and a number of molecules previously not known to be expressed in $B$. colombiensis venom, such as waprin and calcium-binding proteins. However, venom gland transcriptomes based on cloning technologies and random clone selection sequencing may not allow for discovery of rare transcripts due to the recurrent sequencing of more abundant cDNA. Transcriptome analysis using high-throughput RNA-sequence (RNA-seq) would greatly expands the potential for rare transcript discoveries and would provide a much more comprehensive analysis. Our database constitutes the first reference collection of ESTs from $B$. colombiensis. This EST database not only facilitated a better understanding of the pathophysiological effects after envenomation, but also provides a valuable resource for studying structure-function relationships and developing new research tools and therapeutic agents.

\section{Methods}

\section{Venom gland sample collection}

A healthy, 5 years old male B. colombiensis originating from Venezuela and housed at the National Natural Toxins Research Center Serpentarium was sacrificed $\left(\mathrm{CO}_{2}\right)$, its venom gland excised and immediately frozen $(2 \mathrm{~g})$ in liquid nitrogen and stored until used for RNA isolation. Venom was extracted from the snake 4 days prior to sacrificing. The protocol was approved by the IACUC Texas A and M University-Kingsville, Texas, USA.

\section{Total RNA isolation and CDNA library construction}

Venom glands $(10 \mathrm{mg})$ were disrupted with a pestle and mortar in liquid nitrogen, and total RNA was isolated using the NucleoSpin ${ }^{\circledR}$ RNAII kit (Clontech Laboratories, Inc., CA, USA) based on the company's instruction. DNA contamination was removed by an on-column rDNase digestion during the preparation. We recovered $1.4 \mu \mathrm{g}$ of total RNA from $10 \mathrm{mg}$ tissue. The 260/280 absorbance ratios of the total RNA sample was 2.22, indicating purity of the total RNA. The integrity of total RNA was checked by discerning the $28 \mathrm{~S}$ and $18 \mathrm{~S}$ bands of ribosomal RNA in $1.2 \%$ agarose gel by staining with ethidium bromide. The 28S/18S RNA bands showed an intensity ratio of about 2:1 that was considered good 
quality RNA (data not shown). To determine the quantitative and qualitative (RNA quality index, RQI) of the total RNA, the sample was also run through an Experion RNA Analysis Kits using Experion ${ }^{\mathrm{TM}}$ Automated Electrophoresis System (Bio-Rad Laboratories, Inc., USA) and the RQI was 7.4, confirming a high-quality RNA sample to be used for library construction. The RQI score is based on a numbering system from 1 to 10 (in ascending quality). In general, an RQI higher than seven represents an acceptable quality of RNA. A directional cDNA library using $120 \mathrm{ng}$ of total RNA was constructed using the InFusion ${ }^{\circledR}$ SMARTer ${ }^{\text {TM }}$ cDNA Library Construction Kit (Clontech Laboratories, Inc.), which was modified from Suntravat et al. [55]. Briefly, a $120 \mathrm{ng}$ of total RNA from the venom gland was reverse transcribed to the firststrand cDNA using the SMARTScript ${ }^{\mathrm{TM}}$ Reverse Transcriptase (Clontech Laboratories, Inc.) and the In-Fusion SMARTer CDS primer (Clontech Laboratories, Inc.) at $42{ }^{\circ} \mathrm{C}$ for $90 \mathrm{~min}$. Then, double-stranded cDNA (ds cDNA) synthesis was performed on an iCycler Thermal Cycler (Bio-Rad Laboratories, Inc., CA, USA) by LD PCR reaction containing $73 \mu \mathrm{L}$ of deionized $\mathrm{H}_{2} \mathrm{O}, 10 \mu \mathrm{L}$ of 10X Advantage 2 PCR buffer, $10 \mu \mathrm{L}$ of first-strand cDNA, and $2 \mu \mathrm{L}$ of $50 \mathrm{X}$ dNTP Mix, $5^{\prime}$ PCR primer II A, $3^{\prime}$ InFusion SMARTer PCR Primer, and $1 \mu \mathrm{L}$ of 50X Advantage 2 Polymerase Mix. The final volume was $100 \mu \mathrm{L}$. PCR conditions included an initial denaturation step at $95{ }^{\circ} \mathrm{C}$ for $1 \mathrm{~min}$ followed by 18 cycles at $95^{\circ} \mathrm{C}$ for $15 \mathrm{~s}$, at $65^{\circ} \mathrm{C}$ for $30 \mathrm{~s}$, and at $68^{\circ} \mathrm{C}$ for $6 \mathrm{~min}$. Lastly, the ds cDNA was purified using CHROMA SPIN ${ }^{\mathrm{TM}}+\mathrm{TE}-1000$ size exclusion column chromatography (Clontech Laboratories, Inc.). Three microliters of each fraction were electrophoresed on a $1.1 \%$ agarose/EtBr gel to determine the peak fractions by visualizing the intensity of the bands under UV. Fractions containing large-, medium-, and small-sized cDNA were pooled, which was ligated into the pSMART2IFD vector (Clontech Laboratories, Inc.). The resulting ligation reactions were transformed into Stellar ${ }^{\mathrm{TM}}$ Electrocompetent Escherichia coli HST08 strain (Clontech Laboratories, Inc.). The final resulting plasmid library had over 1 million independent clones. The cDNA library constructed is a non-normalized primary library without amplification, so the clone abundance represents the relative mRNA population.

\section{Plasmid preparation and DNA sequencing}

Individual white colonies were randomly selected from a Luria-Bertani (LB) agar plate containing $100 \mu \mathrm{g} /$ $\mathrm{mL}$ ampicillin, $1 \mathrm{mM}$ IPTG, and $75 \mu \mathrm{g} / \mathrm{mL} \mathrm{X-Gal} \mathrm{and}$ inoculated in $5 \mathrm{~mL}$ of $\mathrm{LB}$ and $100 \mu \mathrm{g} / \mathrm{mL}$ ampicillin medium overnight at $37{ }^{\circ} \mathrm{C}$ with shaking at $225 \mathrm{rpm}$ on an Innova ${ }^{\circledR} 43$ incubator shaker (New Brunswick
Scientific, CT, USA). Plasmid DNAs were isolated using the GenElute ${ }^{\mathrm{TM}}$ plasmid miniprep kit (Sigma-Aldrich, MO, USA), according to the manufacture's instruction. Extracted plasmid DNAs were sent out for automated sequencing at the DNA Facility, Office of Biotechnology, Iowa State University, Iowa. All of the cDNA sequences were $5^{\prime}$ sequenced using the forward screening primer (5'-TCACACAGGAAACAGCTATGA-3').

\section{Assembly and identification of ESTs \\ Sequencing analysis}

Sequence chromatograms were processed to remove low quality sequences and poly $\mathrm{A}^{+}$tracts using the Lasergene 12 software (DNASTAR, Inc., Madison, WI). Adapter and vector sequences were then removed using the NCBI VecScreen (http://www.ncbi.nlm.nih.gov/tools/vecscreen/). The processed EST sequence files were assembled into contiguous clusters (including contigs and singletons) using the Lasergene 12 software (DNASTAR). Each EST was searched against the non-redundant database of NCBI using BLASTN and BLASTX algorithms to identify similar sequences with an e-value cutoff $<10^{-5}$ and a minimum coverage of $100 \mathrm{bp}$ [87]. Representative 108 cDNA sequences were submitted to the dbESTs division of GenBank under accession numbers [dbEST: JZ880059-JZ880166].

\section{Additional files}

Additional file 1. Summary of statistics after clustering and assembly of 729 EST sequences.

Additional file 2. A representative list of putative protein identity matches for expressed sequence tags (ESTs) obtained from randomly sequenced clones from B. colombiensis venom gland.

Additional file 3. Relative contributions of the different putative toxins hits in each of the Bothrops snake venom gland transcriptome.

\section{Abbreviations}

BPP/C-NP: Bradykinin-potentiating and C-type natriuretic peptide; CRISP: cysteine-rich secretory protein; CRD: cysteine-rich domain; EST: expressed sequence tag; LAO: L-amino acid oxidase; LIM: lin-11-Caenorhabditis elegans cell lineage gene, isl-1-rat insulin I gene enhancer region-binding protein, mec-3-C. elegans gene required for differentiation of mechanosensory neurons; PLA 2 : phospholipase $A_{2}$; PR-1: pathogenesis-related protein-1; SCP: sperm-coating protein; SVVEGF: snake venom vascular endothelium growth factor; WAP: whey acidic protein.

\section{Authors' contributions}

MS was responsible for most of the experimental work, sequence annotation, data analysis, and wrote the manuscript. MS and NLU created the CDNA library. CA and TJH did part of the experimental work and annotated the sequences. SEL helped draft the manuscript. EES collected the venom gland sample. EES and ARA are the principal investigators who conceived the study, wrote the paper with MS, and critically reviewed the manuscript. All authors read and approved the final manuscript.

\section{Author details}

${ }^{1}$ National Natural Toxins Research Center, Department of Chemistry, Texas A and M University-Kingsville, Kingsville, USA. ${ }^{2}$ Laboratorio de Inmunoquímica 
y Ultraestructura, Instituto Anatómico de la Universidad Central de Venezuela, Caracas, Venezuela.

\section{Acknowledgements}

Funding for the project was provided by the $\mathrm{NIH} /$ Biological Materials Resource Grant, Viper Resource Grant \#s 5P400D010960-12 (NNTRC, Texas A and M University-Kingsville), International Centre for Genetic Engineering and Biotechnology (Universidad Central de Venezuela, Grant \# CRPNEN13-03), and FONACIT (Venezuela) Grant: N2014000490. We want to thank Nora Diaz DeLeon, Mark Hockmuller, Juan Salinas and our NNTRC personnel for their assistance.

\section{Competing interests}

The authors declare that they have no competing interests.

Received: 14 September 2015 Accepted: 23 February 2016

Published online: 05 March 2016

\section{References}

1. Giron ME, Guerrero B, Salazar AM, Sanchez EE, Alvarez M, RodriguezAcosta A. Functional characterization of fibrinolytic metalloproteinases (colombienases) isolated from Bothrops colombiensis venom. Toxicon. 2013;74:116-26

2. Giron ME, Rodriguez-Acosta A, Salazar AM, Sanchez EE, Galan J, Ibarra $C$, et al. Isolation and characterization of two new non-hemorrhagic metalloproteinases with fibrinogenolytic activity from the mapanare (Bothrops colombiensis) venom. Arch Toxicol. 2013;87(1):197-208.

3. Giron ME, Salazar AM, Aguilar I, Perez JC, Sanchez EE, ArochaPinango CL, et al. Hemorrhagic, coagulant and fibrino(geno)lytic activities of crude venom and fractions from mapanare (Bothrops colombiensis) snakes. Comp Biochem Physiol C: Toxicol Pharmacol. 2008;147(1):113-21.

4. Salazar AM, Rodriguez-Acosta A, Giron ME, Aguilar I, Guerrero B. A comparative analysis of the clotting and fibrinolytic activities of the snake venom (Bothrops atrox) from different geographical areas in Venezuela. Thromb Res. 2007;120(1):95-104.

5. de Selistre Araujo HS, de Souza DH, Ownby CL. Analysis of a CDNA sequence encoding a novel member of the snake venom metalloproteinase, disintegrin-like, cysteine-rich (MDC) protein family from Agkistrodon contortrix laticinctus. Biochim Biophys Acta. 1997;1342(2):109-15.

6. Bjarnason JB, Fox JW. Hemorrhagic metalloproteinases from snake venoms. Pharmacol Ther. 1994;62(3):325-72.

7. Duque J, Sánchez A, Fierro L, Garzón S, Castaño R. Venenos de serpientes y moléculas antiveneno. Rev Acad Colomb Cienc. 2007;31:109-37.

8. Rodriguez-Acosta A, Sanchez EE, Marquez A, Carvajal Z, Salazar AM, Giron ME, et al. Hemostatic properties of Venezuelan Bothrops snake venoms with special reference to Bothrops isabelae venom. Toxicon. 2010;56(6):926-35.

9. Lancini AR, Kornacker PM. Die Schlangen von Venezuela. 3rd ed. Caracas; 1989.

10. Cruz LS, Vargas R, Lopes AA. Snakebite envenomation and death in the developing world. Ethn Dis. 2009;19(1 suppl 1):42-6.

11. Calvete JJ, Borges A, Segura A, Flores-Diaz M, Alape-Giron A, Gutierrez $J M$, et al. Snake venomics and antivenomics of Bothrops colombiensis, a medically important pitviper of the Bothrops atrox-asper complex endemic to Venezuela: contributing to its taxonomy and snakebite management. J Proteomics. 2009;72(2):227-40.

12. Rokyta DR, Wray KP, McGivern JJ, Margres MJ. The transcriptomic and proteomic basis for the evolution of a novel venom phenotype within the Timber Rattlesnake (Crotalus horridus). Toxicon. 2015;98:34-48.

13. Rodrigues RS, Boldrini-Franca J, Fonseca FP, de la Torre P, HenriqueSilva F, Sanz L, et al. Combined snake venomics and venom gland transcriptomic analysis of Bothropoides pauloensis. J Proteomics. 2012;75(9):2707-20

14. Fry BG, Roelants K, Winter K, Hodgson WC, Griesman L, Kwok HF, et al. Novel venom proteins produced by differential domain-expression strategies in beaded lizards and gila monsters (genus Heloderma). Mol Biol Evol. 2010;27(2):395-407.
15. Fry BG, Scheib H, de Azevedo IDLJ, Silva DA, Casewell NR. Novel transcripts in the maxillary venom glands of advanced snakes. Toxicon. 2012;59(7-8):696-708.

16. Siang AS, Doley R, Vonk FJ, Kini RM. Transcriptomic analysis of the venom gland of the red-headed krait (Bungarus flaviceps) using expressed sequence tags. BMC Mol Biol. 2010;11:24.

17. Wagstaff SC, Harrison RA. Venom gland EST analysis of the saw-scaled viper, Echis ocellatus, reveals novel alpha9beta1 integrin-binding motifs in venom metalloproteinases and a new group of putative toxins, renin-like aspartic proteases. Gene. 2006;377:21-32.

18. Francischetti IM, My-Pham V, Harrison J, Garfield MK, Ribeiro JM. Bitis gabonica (Gaboon viper) snake venom gland: toward a catalog for the full-length transcripts (cDNA) and proteins. Gene. 2004;337:55-69.

19. Junqueira-de-Azevedolde L, Ho PL. A survey of gene expression and diversity in the venom glands of the pitviper snake Bothrops insularis through the generation of expressed sequence tags (ESTs). Gene. 2002;299(1-2):279-91.

20. Bernardoni JL, Sousa LF, Wermelinger LS, Lopes AS, Prezoto BC, Serrano $S M$, et al. Functional variability of snake venom metalloproteinases: adaptive advantages in targeting different prey and implications for human envenomation. PLOS ONE. 2014;9(10):e109651.

21. Fernandez J, Caccin P, Koster G, Lomonte B, Gutierrez JM, Montecucco C, et al. Muscle phospholipid hydrolysis by Bothrops asper Asp49 and Lys49 phospholipase A(2) myotoxins-distinct mechanisms of action. FEBS J. 2013;280(16):3878-86.

22. Ohler M, Georgieva D, Seifert J, von Bergen M, Arni RK, Genov N, et al. The venomics of Bothrops alternatus is a pool of acidic proteins with predominant hemorrhagic and coagulopathic activities. J Proteome Res. 2010;9(5):2422-37.

23. Angulo Y, Lomonte B. Biochemistry and toxicology of toxins purified from the venom of the snake Bothrops asper. Toxicon. 2009;54(7):949-57.

24. Cardoso KC, Da Silva MJ, Costa GG, Torres TT, Del Bem LE, Vidal RO, et al. A transcriptomic analysis of gene expression in the venom gland of the snake Bothrops alternatus (urutu). BMC Genom. 2010;11:605.

25. Neiva M, Arraes FB, de Souza JV, Radis-Baptista G, Prieto da Silva AR, Walter ME, et al. Transcriptome analysis of the Amazonian viper Bothrops atrox venom gland using expressed sequence tags (ESTs). Toxicon. 2009;53(4):427-36.

26. Zelanis A, Andrade-Silva D, Rocha MM, Furtado MF, Serrano SM, Junqueira-de-Azevedo IL, et al. A transcriptomic view of the proteome variability of newborn and adult Bothrops jararaca snake venoms. PLoS Negl Trop Dis. 2012;6(3):e1554.

27. Cidade DA, Simao TA, Davila AM, Wagner G, Junqueira-de-Azevedo IL, $\mathrm{Ho} \mathrm{PL}$, et al. Bothrops jararaca venom gland transcriptome: analysis of the gene expression pattern. Toxicon. 2006;48(4):437-61.

28. Markland FS. Snake venoms and the hemostatic system. Toxicon. 1998:36(12):1749-800.

29. Bjarnason JB, Fox JW. Snake venom metalloendopeptidases: reprolysins. Methods Enzymol. 1995;248:345-68.

30. Hite LA, Jia LG, Bjarnason JB, Fox JW. cDNA sequences for four snake venom metalloproteinases: structure, classification, and their relationship to mammalian reproductive proteins. Arch Biochem Biophys. 1994;308(1):182-91.

31. Markland FS Jr, Swenson S. Snake venom metalloproteinases. Toxicon. 2013;62:3-18.

32. Brass LF, Jiang H, Wu J, Stalker TJ, Zhu L. Contact-dependent signaling events that promote thrombus formation. Blood Cells Mol Dis. 2006;36(2):157-61.

33. Clark EA, Trikha M, Markland FS, Brugge JS. Structurally distinct disintegrins contortrostatin and multisquamatin differentially regulate platelet tyrosine phosphorylation. J Biol Chem. 1994;269(35):21940-3.

34. Stalker TJ, Welsh JD, Tomaiuolo M, Wu J, Colace TV, Diamond SL, et al. A systems approach to hemostasis: 3. Thrombus consolidation regulates intrathrombus solute transport and local thrombin activity. Blood. 2013;124(11):1824-31.

35. Brass LF, Zhu L, Stalker TJ. Minding the gaps to promote thrombus growth and stability. J Clin Invest. 2005;115(12):3385-92.

36. Marcus AJ, Safier LB. Thromboregulation: multicellular modulation of platelet reactivity in hemostasis and thrombosis. FASEB J. 1993;7(6):516-22. 
37. Selistre de Araujo HS. Ownby CL. Molecular cloning and sequence analysis of cDNAs for metalloproteinases from broad-banded copperhead Agkistrodon contortrix laticinctus. Arch Biochem Biophys. 1995;320(1):141-8.

38. Yamada D, Shin Y, Morita T. Nucleotide sequence of a CDNA encoding a common precursor of disintegrin flavostatin and hemorrhagic factor HR2a from the venom of Trimeresurus flavoviridis. FEBS Lett. 1999;451(3):299-302.

39. Tselepis VH, Green LJ, Humphries MJ. An RGD to LDV motif conversion within the disintegrin kistrin generates an integrin antagonist that retains potency but exhibits altered receptor specificity. Evidence for a functional equivalence of acidic integrin-binding motifs. J Biol Chem. 1997;272(34):21341-8.

40. Au LC, Huang YB, Huang TF, Teh GW, Lin HH, Choo KB. A common precursor for a putative hemorrhagic protein and rhodostomin, a platelet aggregation inhibitor of the venom of Calloselasma rhodostoma: molecular cloning and sequence analysis. Biochem Biophys Res Commun. 1991;181(2):585-93

41. Fox JW, Arruda Macedo JK, de SouzaCastro M. Disintegrins from Snake Venoms and their Applications in Cancer Research and Therapy. Curr Protein Pept Sci. 2015;16(6):532-48.

42. Suntravat M, Barret HS, Jurica CA, Lucena SE, Perez JC, Sanchez EE. Recombinant disintegrin ( $r$-Cam-dis) from Crotalus adamanteus inhibits adhesion of human pancreatic cancer cell lines to laminin-1 and vitronectin. J Venom Res. 2015;6:1-10.

43. Carey CM, Bueno R, Gutierrez DA, Petro C, Lucena SE, Sanchez EE, et al. Recombinant rubistatin ( $r$-Rub), an MVD disintegrin, inhibits cell migration and proliferation, and is a strong apoptotic inducer of the human melanoma cell line SK-Mel-28. Toxicon. 2012;59(2):241-8.

44. Lucena S, Castro R, Lundin C, Hofstetter A, Alaniz A, Suntravat M, et al. Inhibition of pancreatic tumoral cells by snake venom disintegrins. Toxicon. 2015;93:136-43.

45. Lucena SE, Jia Y, Soto JG, Parral J, Cantu E, Brannon J, et al. Anti-invasive and anti-adhesive activities of a recombinant disintegrin, $r$-viridistatin 2 , derived from the Prairie rattlesnake (Crotalus viridis viridis). Toxicon. 2012;60(1):31-9.

46. Sanchez EE, Rodriguez-Acosta A, Palomar R, Lucena SE, Bashir S, Soto $J G$, et al. Colombistatin: a disintegrin isolated from the venom of the South American snake (Bothrops colombiensis) that effectively inhibits platelet aggregation and SK-Mel-28 cell adhesion. Arch Toxicol. 2009;83(3):271-9.

47. Higuchi DA, Almeida MC, Barros CC, Sanchez EF, Pesquero PR, Lang EA, et al. Leucurogin, a new recombinant disintegrin cloned from Bothrops leucurus (white-tailed-jararaca) with potent activity upon platelet aggregation and tumor growth. Toxicon. 2011;58(1):123-9.

48. Swenson S, Ramu S, Markland FS. Anti-angiogenesis and RGD-containing snake venom disintegrins. Curr Pharm Des. 2007;13(28):2860-71.

49. Marcussi S, Bernardes CP, Santos-Filho NA, Mazzi MV, Oliveira CZ, Izidoro $L F$, et al. Molecular and functional characterization of a new non-hemorrhagic metalloprotease from Bothrops jararacussu snake venom with antiplatelet activity. Peptides. 2007;28(12):2328-39.

50. da Silva IR, Lorenzetti R, Renno AL, Baldissera L Jr, Zelanis A, Serrano SM, et al. BJ-PI2, a non-hemorrhagic metalloproteinase from Bothrops jararaca snake venom. Biochim Biophys Acta. 2012;1820(11):1809-21.

51. Rodrigues VM, Soares AM, Guerra-Sa R, Rodrigues V, Fontes MR, Giglio JR. Structural and functional characterization of neuwiedase, a nonhemorrhagic fibrin(ogen)olytic metalloprotease from Bothrops neuwiedi snake venom. Arch Biochem Biophys. 2000;381(2):213-24.

52. Sun DJ, Gu HD, Yang CW, Hu CG, Yang TS, Yan WQ. Molecular cloning and sequence analysis of ussurin, a new metalloproteinases/disintegrin from Gloydius ussuriensis. Sheng Wu Gong Cheng Xue Bao. 2003;19(3):353-7.

53. Jia LG, Shimokawa K, Bjarnason JB, Fox JW. Snake venom metalloproteinases: structure, function and relationship to the ADAMs family of proteins. Toxicon. 1996;34(11-12):1269-76.

54. Kini RM, Evans HJ. Structural domains in venom proteins: evidence that metalloproteinases and nonenzymatic platelet aggregation inhibitors (disintegrins) from snake venoms are derived by proteolysis from a common precursor. Toxicon. 1992;30(3):265-93.

55. Suntravat M, Jia Y, Lucena SE, Sanchez EE, Perez JC. CDNA cloning of a snake venom metalloproteinase from the eastern diamondback rattlesnake (Crotalus adamanteus), and the expression of its disintegrin domain with anti-platelet effects. Toxicon. 2013;64:43-54.

56. Suntravat M, Yusuksawad M, Sereemaspun A, Perez JC, Nuchprayoon I. Effect of purified Russell's viper venom-factor X activator (RV-X) on renal hemodynamics, renal functions, and coagulopathy in rats. Toxicon. 2011;58(3):230-8. doi:10.1016/j.toxicon.2011.05.007.

57. Sanchez EE, Galan JA, Powell RL, Reyes SR, Soto JG, Russell WK, et al. Disintegrin, hemorrhagic, and proteolytic activities of Mohave rattlesnake, Crotalus scutulatus scutulatus venoms lacking Mojave toxin. Comp Biochem Physiol C: Toxicol Pharmacol. 2005;141(2):124-32.

58. Sanchez EE, Galan JA, Russell WK, Soto JG, Russell DH, Perez JC. Isolation and characterization of two disintegrins inhibiting ADPinduced human platelet aggregation from the venom of Crotalus scutulatus scutulatus (Mohave Rattlesnake). Toxicol Appl Pharmacol. 2006;212(1):59-68.

59. Sanchez EE, Lucena SE, Reyes S, Soto JG, Cantu E, Lopez-Johnston JC, et al. Cloning, expression, and hemostatic activities of a disintegrin, r-mojastin 1, from the mohave rattlesnake (Crotalus scutulatus scutulatus). Thromb Res. 2010;126(3):e211-9.

60. Jia Y, Lucena S, Cantu E Jr, Sanchez EE, Perez JC. cDNA cloning, expression and fibrin(ogen)olytic activity of two low-molecular weight snake venom metalloproteinases. Toxicon. 2009;54(3):233-43.

61. Da Silva M, Lucena S, Aguilar I, Rodriguez-Acosta A, Salazar AM, Sanchez $\mathrm{EE}$, et al. Anti-platelet effect of cumanastatin 1, a disintegrin isolated from venom of South American Crotalus rattlesnake. Thromb Res. 2009;123(5):731-9.

62. Gutierrez JM, Lomonte B. Phospholipases A2: unveiling the secrets of a functionally versatile group of snake venom toxins. Toxicon. 2013;62:27-39.

63. Doley R, Kini RM. Protein complexes in snake venom. Cell Mol Life Sci. 2009;66(17):2851-71.

64. Kashima S, Roberto PG, Soares AM, Astolfi-Filho S, Pereira JO, Giuliati S, et al. Analysis of Bothrops jararacussu venomous gland transcriptome focusing on structural and functional aspects: i-gene expression profile of highly expressed phospholipases A2. Biochimie. 2004;86(3):211-9.

65. Durban J, Juarez P, Angulo Y, Lomonte B, Flores-Diaz M, Alape-Giron A, et al. Profiling the venom gland transcriptomes of Costa Rican snakes by 454 pyrosequencing. BMC Genom. 2011;12:259.

66. Dos Santos JI, Cardoso FF, Soares AM, Dal Pai Silva M, Gallacci M, Fontes MR. Structural and functional studies of a bothropic myotoxin complexed to rosmarinic acid: new insights into Lys49-PLA(2) inhibition. PLOS ONE. 2011;6(12):e28521.

67. Toyama MH, Costa PD, Novello JC, de Oliveira B, Giglio JR, da CruzHofling MA, et al. Purification and amino acid sequence of MP-III 4R D49 phospholipase A2 from Bothrops pirajai snake venom, a toxin with moderate PLA2 and anticoagulant activities and high myotoxic activity. J Protein Chem. 1999;18(3):371-8.

68. Mancuso LC, Correa MM, Vieira CA, Cunha OA, Lachat JJ, de Araujo $\mathrm{HS}$, et al. Fractionation of Bothrops pirajai snake venom: isolation and characterization of piratoxin-I, a new myotoxic protein. Toxicon. 1995;33(5):615-26.

69. Serrano SM. The long road of research on snake venom serine proteinases. Toxicon. 2013;62:19-26.

70. Kini RM. Serine proteases affecting blood coagulation and fibrinolysis from snake venoms. Pathophysiol Haemost Thromb. 2005;34(4-5):200-4.

71. Serrano SM, Maroun RC. Snake venom serine proteinases: sequence homology vs. substrate specificity, a paradox to be solved. Toxicon. 2005;45(8):1115-32.

72. Nair DG, Fry BG, Alewood P, Kumar PP, Kini RM. Antimicrobial activity of omwaprin, a new member of the waprin family of snake venom proteins. Biochem J. 2007;402(1):93-104.

73. Torres AM, Wong HY, Desai M, Moochhala S, Kuchel PW, Kini RM. Identification of a novel family of proteins in snake venoms. Purification and structural characterization of nawaprin from Naja nigricollis snake venom. J Biol Chem. 2003;278(41):40097-104.

74. Jackson TN, Sunagar K, Undheim EA, Koludarov I, Chan AH, Sanders K, et al. Venom down under: dynamic evolution of Australian elapid snake toxins. Toxins (Basel). 2013;5(12):2621-55.

75. Fry BG, Scheib H, van der Weerd L, Young B, McNaughtan J, Ramjan SF, et al. Evolution of an arsenal: structural and functional diversification 
of the venom system in the advanced snakes (Caenophidia). Mol Cell Proteomics. 2008;7(2):215-46.

76. Clemetson KJ. Snaclecs (snake C-type lectins) that inhibit or activate platelets by binding to receptors. Toxicon. 2010;56(7):1236-46.

77. Oliveira-Carvalho AL, Guimaraes PR, Abreu PA, Dutra DL, Junqueira-deAzevedo IL, Rodrigues CR, et al. Identification and characterization of a new member of snake venom thrombin inhibitors from Bothrops insularis using a proteomic approach. Toxicon. 2008;51(4):659-71.

78. Valente RH, Guimaraes PR, Junqueira M, Neves-Ferreira AG, Soares MR, Chapeaurouge A, et al. Bothrops insularis venomics: a proteomic analysis supported by transcriptomic-generated sequence data. J Proteomics. 2009;72(2):241-55.

79. Dhananjaya BL, D'Souza CJ. The pharmacological role of nucleotidases in snake venoms. Cell Biochem Funct. 2010;28(3):171-7.

80. Aird SD. Ophidian envenomation strategies and the role of purines. Toxicon. 2002;40(4):335-93.

81. Seligmann C, Kupatt C, Becker BF, Zahler S, Beblo S. Adenosine endogenously released during early reperfusion mitigates postischemic myocardial dysfunction by inhibiting platelet adhesion. J Cardiovasc Pharmacol. 1998;32(1):156-63.

82. Sobrevia L, Yudilevich DL, Mann GE. Activation of A2-purinoceptors by adenosine stimulates L-arginine transport (system $y+$ ) and nitric oxide synthesis in human fetal endothelial cells. J Physiol. 1997;499(Pt 1):135-40.

83. Hargreaves MB, Stoggall SM, Collis MG. Evidence that the adenosine receptor mediating relaxation in dog lateral saphenous vein and guinea pig aorta is of the A2B subtype. Br J Pharmacol. 1991;102:198.

84. Jimenez-Charris E, Montealegre-Sanchez L, Solano-Redondo L, MoraObando D, Camacho E, Castro-Herrera F, et al. Proteomic and functional analyses of the venom of Porthidium lansbergii lansbergii (Lansberg's hognose viper) from the Atlantic Department of Colombia. J Proteomics. 2015;114:287-99.

85. Aird SD, Watanabe Y, Villar-Briones A, Roy MC, Terada K, Mikheyev AS. Quantitative high-throughput profiling of snake venom gland transcriptomes and proteomes (Ovophis okinavensis and Protobothrops flavoviridis). BMC Genom. 2013;14:790.

86. Rokyta DR, Lemmon AR, Margres MJ, Aronow K. The venom-gland transcriptome of the eastern diamondback rattlesnake (Crotalus adamanteus). BMC Genom. 2011;13:312.

87. Pahari S, Mackessy SP, Kini RM. The venom gland transcriptome of the Desert Massasauga rattlesnake (Sistrurus catenatus edwardsii): towards an understanding of venom composition among advanced snakes (Superfamily Colubroidea). BMC Mol Biol. 2007;8:115.

88. Zhang B, Liu Q, Yin W, Zhang X, Huang Y, Luo Y, et al. Transcriptome analysis of Deinagkistrodon acutus venomous gland focusing on cellular structure and functional aspects using expressed sequence tags. BMC Genom. 2006;7:152.

89. Estrella A, Sanchez EE, Galan JA, Tao WA, Guerrero B, Navarrete LF, et al. Characterization of toxins from the broad-banded water snake Helicops angulatus (Linnaeus, 1758): isolation of a cysteine-rich secretory protein, Helicopsin. Arch Toxicol. 2011;85(4):305-13.

90. Gibbs GM, O'Bryan MK. Cysteine rich secretory proteins in reproduction and venom. Soc Reprod Fertil Suppl. 2007;65:261-7.

91. Guo M, Teng M, Niu L, Liu Q, Huang Q, Hao Q. Crystal structure of the cysteine-rich secretory protein stecrisp reveals that the cysteinerich domain has a $\mathrm{K}+$ channel inhibitor-like fold. J Biol Chem. 2005;280(13):12405-12.

92. Peichoto ME, Mackessy SP, Teibler P, Tavares FL, Burckhardt PL, Breno $\mathrm{MC}$, et al. Purification and characterization of a cysteine-rich secretory protein from Philodryas patagoniensis snake venom. Comp Biochem Physiol C: Toxicol Pharmacol. 2009;150(1):79-84.

93. Yamazaki Y, Morita T. Structure and function of snake venom cysteinerich secretory proteins. Toxicon. 2004;44(3):227-31.

94. Junqueira de Azevedo IL, Farsky SH, Oliveira ML, Ho PL. Molecular cloning and expression of a functional snake venom vascular endothelium growth factor (VEGF) from the Bothrops insularis pit viper. A new member of the VEGF family of proteins. J Biol Chem. 2001;276(43):39836-42.

95. Takahashi H, Hattori S, Iwamatsu A, Takizawa H, Shibuya M. A novel snake venom vascular endothelial growth factor (VEGF) predominantly induces vascular permeability through preferential signaling via VEGF receptor-1. J Biol Chem. 2004;279(44):46304-14.

96. Izidoro LF, Sobrinho JC, Mendes MM, Costa TR, Grabner AN, Rodrigues VM, et al. Snake venom L-amino acid oxidases: trends in pharmacology and biochemistry. Biomed Res Int. 2014;2014:196754.

97. Hayashi MA, Camargo AC. The Bradykinin-potentiating peptides from venom gland and brain of Bothrops jararaca contain highly site specific inhibitors of the somatic angiotensin-converting enzyme. Toxicon. 2005;45(8):1163-70.

98. Lumsden NG, Khambata RS, Hobbs AJ. C-type natriuretic peptide (CNP): cardiovascular roles and potential as a therapeutic target. Curr Pharm Des. 2010;16(37):4080-8.

99. Hayashi MA, Murbach AF, lanzer D, Portaro FC, Prezoto BC, Fernandes $\mathrm{BL}$, et al. The C-type natriuretic peptide precursor of snake brain contains highly specific inhibitors of the angiotensin-converting enzyme. J Neurochem. 2003;85(4):969-77.

100. Murayama N, Hayashi MA, Ohi H, Ferreira LA, Hermann WV, Saito H, et al. Cloning and sequence analysis of a Bothrops jararaca cDNA encoding a precursor of seven bradykinin-potentiating peptides and a C-type natriuretic peptide. Proc Natl Acad Sci USA. 1997;94(4):1189-93.

101. Margres MJ, McGivern JJ, Wray KP, Seavy M, Calvin K, Rokyta DR. Linking the transcriptome and proteome to characterize the venom of the eastern diamondback rattlesnake (Crotalus adamanteus). J Proteomics. 2014;96:145-58.

102. Saviola AJ, Pla D, Sanz L, Castoe TA, Calvete JJ, Mackessy SP. Comparative venomics of the Prairie Rattlesnake (Crotalus viridis viridis) from Colorado: identification of a novel pattern of ontogenetic changes in venom composition and assessment of the immunoreactivity of the commercial antivenom CroFab(R). J Proteomics. 2015;121:28-43.

103. Sousa LF, Nicolau CA, Peixoto PS, Bernardoni JL, Oliveira SS, PortesJunior JA, et al. Comparison of phylogeny, venom composition and neutralization by antivenom in diverse species of bothrops complex. PLoS Negl Trop Dis. 2013;7(9):e2442.

104. Viala VL, Hildebrand D, Trusch M, Arni RK, Pimenta DC, Schluter H, et al. Pseudechis guttatus venom proteome: insights into evolution and toxin clustering. J Proteomics. 2014;110:32-44.

105. Bernheimer AW, Linder R, Weinstein SA, Kim KS. Isolation and characterization of a phospholipase B from venom of Collett's snake, Pseudechis colletti. Toxicon. 1987;25(5):547-54.

106. Bernheimer AW, Weinstein SA, Linder R. Isoelectric analysis of some Australian elapid snake venoms with special reference to phospholipase B and hemolysis. Toxicon. 1986;24(8):841-9.

107. Takasaki C, Tamiya N. Isolation and properties of lysophospholipases from the venom of an Australian elapid snake, Pseudechis australis. Biochem J. 1982;203(1):269-76.

108. Doery HM, Pearson JE. Phospholipase B in snake venoms and bee venom. Biochem J. 1964;92(3):599-602.

109. Goncalves LR, Yamanouye N, Nunez-Burgos GB, Furtado MF, Britto LR, Nicolau J. Detection of calcium-binding proteins in venom and Duvernoy's glands of South American snakes and their secretions. Comp Biochem Physiol C: Pharmacol Toxicol Endocrinol. 1997;118(2):207-11.

110. Rodriguez C, Omana B. Clinica y tratamiento de los accidentes ofidicos de Venezuela. Mimeo. Caracas: Hospital Leopoldo Mantique T; 1999.

111. Mamede CC, de Queiroz MR, Fonseca KC, de Morais NC, Filho SA, Beletti $M E$, et al. Histological and ultrastructural analyses of muscle damage induced by a myotoxin isolated from Bothrops alternatus snake venom. Protein Pept Lett. 2013;20(2):192-9.

112. McCleary RJ, Kini RM. Snake bites and hemostasis/thrombosis. Thromb Res. 2013;132(6):642-6.

113. Gutierrez JM, Escalante T, Rucavado A. Experimental pathophysiology of systemic alterations induced by Bothrops asper snake venom. Toxicon. 2009;54(7):976-87. 